\section{Estudo \\ CoDebate}

em Cestão

Plamejamento
Revista Estudo \& Debate, Lajeado, v. 26, n. 3, 2019. ISSN 1983-036X

DOI: http://dx.doi.org/10.22410/issn.1983-036X.v26i3a2019.1993

\title{
O PECADO ORIGINAL DOMÉSTICO: UMA ANÁLISE DA EXPERIÊNCIA BRASILEIRA ENTRE 2001 A 2016
}

\author{
Édivo de Almeida Oliveira ${ }^{1}$, Paulo Ricardo Feistel ${ }^{2}$, William Barbosa ${ }^{3}$
}

\begin{abstract}
Resumo: Dentre os fenômenos advindos da hierarquia das moedas nacionais destaca-se o pecado original doméstico relacionado com a dificuldade que alguns países apresentam na emissão de títulos da dívida no mercado interno denominado em moeda local e que sejam, simultaneamente, prefixados e de longo prazo. O presente trabalho tem o objetivo de discutir o pecado original doméstico, entre 2001 a abril de 2016, no mercado de títulos federais no Brasil. Constatou-se que a dívida pública mobiliária federal interna se caracteriza por ser indexada à inflação, com significativa participação dos prefixados de baixa maturidade e de títulos indexados à SELIC. Evidenciou-se que as medidas implementadas pelo Governo Federal ao longo da década de 2000, levaram a uma mudança na forma de manifestação do pecado original, entretanto, sem qualquer alteração sensível em sua aguda magnitude.
\end{abstract}

Palavras-chave: Pecado Original. Moedas. Dívida Interna.

\section{THE ORIGINAL DOMESTIC SIN: AN ANALYSIS OF THE BRAZILIAN EXPERIENCE BETWEEN 2001 TO 2016}

\begin{abstract}
Among the phenomena arising from the hierarchy of national currencies is the original domestic sin related to the difficulty that some countries present in the issuance of debt securities in the domestic market denominated in local currency and that are simultaneously fixed and long term. The present work has the objective of discussing the domestic original sin, between 2001 and April 2016, in the federal securities market in Brazil. It was observed that domestic federal securities debt is characterized by being indexed to inflation,
\end{abstract}

1 Doutorando em Economia pela Universidade Estadual de Campinas (UNICAMP). Mestre em Economia pela Universidade Federal de Santa Maria (UFSM). Economista, Bacharel em Ciências Econômicas pela Universidade Estadual do Sudoeste da Bahia (2014). E-mail: edivokin@hotmail.com.

2 Professor adjunto do Departamento de Economia e do Programa de Pós-Graduação em Economia e Desenvolvimento (PPGE\&D). Doutor pela Universidade Federal de Pernambuco (2006). Mestre em Economia pela Universidade Federal de Pernambuco (1997). Economista, Bacharel em Ciências Econômicas pela Universidade Federal de Santa Maria (1985). E-mail: prfeistel@yahoo.com.br.

3 Doutorando em Economia Aplicada pela Universidade de São Paulo (USP/ESALQ). Mestre em Economia pela Universidade Federal de Santa Maria (UFSM). Economista, Bacharel em Ciências Econômicas pela Universidade Estadual de Ponta Grosa (2014). E-mail: williambarbosa@usp.br 
with significant participation of low maturity fixed rate securities and SELIC indexed securities. It was observed that the measures implemented by the Federal Government during the decade of 2000, led to a change in the form of manifestation of original sin, however, without any sensible alteration in its acute magnitude.

Palavras-chave: Original Domestic Sin. National Currencies. Internal Debt.

Classificaçáo JEL: E42, E44, G12, H72, H81.

\section{Introduçáa}

Uma das características principais do SMI vigente, consiste no caráter hierarquizado da sua estrutura que, entre outras implicaçóes, atua de modo a impor às economias menores e emissoras de moedas "fracas" ou inconversíveis uma menor capacidade de financiamento, maior instabilidade dos fluxos de capital e menor autonomia quanto à implementaçáo de políticas de estabilização macroeconômica. $\mathrm{O}$ estudo sistemático das consequências adversas que decorrem da hierarquização da moeda em âmbito internacional ganhou novo vigor com as contribuiçóes de Eichengreen e Hausmann (1999). Coube a esses autores identificarem o fenômeno que denominaram de original sin (pecado original), cuja dimensão doméstica consiste na dificuldade apresentada pelos países menos desenvolvidos em emitirem títulos da dívida, sobretudo, prefixados e denominados em moeda nacional na tomada de empréstimos de longo prazo no próprio mercado local.

Níveis elevados de pecado original doméstico estão intrinsecamente associados à dificuldade do setor público de emitirem títulos prefixados da dívida, com prazos de maturidade mais longos no âmbito do mercado nacional. Na presença dessa disfunção, o Governo $^{4}$ enfrenta o trade-off entre se endividar no longo prazo em moeda estrangeira "forte", ou se endividar no curto prazo em moeda doméstica. Além disso, a presença do pecado original nas economias menos desenvolvidas pode implicar em um crítico descasamento tanto de moedas quanto de prazos no balanço de pagamentos e nas contas públicas, com implicaçóes negativas à economia nacional em períodos de desvalorização cambial e de elevação da taxa de juros (EICHENGREEN; HAUSMANN, 1999).

Depreende-se que a substituição monetária ocorrida no Brasil, combinada com a elevação do endividamento público via emissão de títulos de curto prazo e indexados ao câmbio e à taxa de juros, reflete a incapacidade do setor público brasileiro de endividar-se a longo prazo em moeda nacional, mesmo no âmbito do mercado doméstico. Esse problema remonta o contexto do endividamento público brasileiro ao longo da década de 1990, bem como os dois primeiros anos da década de 2000; nesse último caso em funçáo dos efeitos internos engendrados pela crise energética e argentina, além do ataque terrorista de 11 de setembro nos EUA.

Indícios sinalizam mudanças no perfil da dívida mobiliária interna, com implicaçóes sobre a manifestação do pecado doméstico no Brasil a partir do ano de 2002, ao iniciar

4 As mudanças no perfil do endividamento público induzem ao setor privado nacional a acompanhá-las no que se refere aos prazos de maturidade, remuneração e às garantias das suas emissões (BUENO, 2007). Isso porque o Governo influencia decisivamente no estabelecimento das taxas básicas de retorno e atua como referência máxima de solvência para os demais agentes internos e externos. 
uma tendência de queda dos títulos indexados à taxa de câmbio e à SELIC 5 . Além disso, aumentou-se tanto a emissão de títulos prefixados, quanto à liquidez dos títulos públicos. A década de 2000 experimentou uma mudança considerável no perfil da dívida pública brasileira, em função do aumento da dívida mobiliária interna e do recuo da dívida pública externa (BACEN, 2009).

Recentemente, no período pós-2010 existem evidências de que o passivo interno se manteve em ascensão, dado a deterioração dos indicadores macroeconômicos. Athayde e Vianna (2015) relatam que a tendência de queda da dívida bruta brasileira foi interrompida em função da perda do dinamismo interno, aliada a uma mudança significativa na estratégia de política fiscal adotada pelo Governo. Conforme Cruz (2016), a dívida pública bruta como proporção do PIB segue uma trajetória ascendente que se acentuou recentemente, chegando a 64,5\% em julho de 2015. Essa tendência de elevação também é apresentada pela dívida pública líquida como proporção do PIB nesse mesmo período. Esse quadro reflete os efeitos do grau de instabilidade do cenário macroeconômico do País face à crise econômica e política sobre os mecanismos de financiamento público, ao sinalizar uma deterioração da sua capacidade de solvência e perda de credibilidade junto aos investidores estrangeiros, que estâo entre os principais detentores da dívida interna soberana do Brasil.

Portanto, é possível conjecturar que o cenário conjuntural e macroeconômico, a partir de 2011, tenha impactado negativamente na capacidade do setor público de contrair dívida de longo prazo, denominada em moeda doméstica no mercado financeiro interno. Diante desse contexto, o presente trabalho se insere nessa discussáo com o objetivo de investigar se houve, e em que magnitude esteve o pecado original doméstico no Brasil, entre janeiro de 2001 a abril de 2016. Caso seja confirmada a sua existência, será possível identificar se houve recuo, estagnação ou avanço desse fenômeno no âmbito da economia brasileira durante o período considerado. A despeito da contribuição de Hausmann e Panizza (2003) e de Gomes et. al (2007), a presente pesquisa busca complementar e avançar em relação às análises realizadas por esses estudos. Para tanto, o recorte temporal adotado na presente pesquisa objetiva, simultaneamente, retroceder o suficiente para abranger as mudanças no perfil e nas condiçóes do endividamento público mobiliário brasileiro processadas ao longo da década de $2000^{6}$, e perpassar pelos períodos de crise internacional deflagrados nesse decênio, sem negligenciar os eventos recentes mais relevantes observados na economia nacional.

5 Significa Sistema Especial de Liquidação e Custódia e refere-se à taxa básica de juros da economia brasileira.

6 A partir do ano de 2000 o modelo orçamentário do Governo experimenta um processo de reformulaçáo, com o objetivo de se adequar às exigências impostas pela Lei de Responsabilidade Fiscal. Os anos subsequentes são marcados pelo esforço do Tesouro de incorporar maior detalhamento e precisão no que se refere às análises financeiras e orçamentárias, bem como na demonstração dos resultados e desdobramentos sociais dos gastos públicos e de sua forma de financiamento. Portanto, a adoção do ano de 2001 como ponto inicial do presente estudo também se deve a estratégia da pesquisa adotada, que visa empregar o banco de dados mais robusto e confiável disponível em sítios oficiais, quanto ao endividamento mobiliário do setor público no Brasil, com o intuito de evitar-se distorçôes no cálculo dos índices do pecado original doméstico. 
A problemática que norteia o trabalho pode ser enunciada como segue: qual foi o comportamento do pecado original doméstico brasileiro entre janeiro de 2001 a junho de 2016? Os objetivos do estudo consistem em: i) analisar o comportamento e o perfil da dívida pública interna brasileira; ii) e calcular os índices para a mensuração do pecado original doméstico no interregno circunscrito entre janeiro de 2001 a junho de 2016. O método empregado consiste nos cálculos dos índices sugeridos por Hausmann e Panizza (2003), referentes à dimensão doméstica do pecado original para o Brasil no período considerado. A escassa literatura nacional pautada em investigaçóes empíricas sobre o fenômeno em questão, sanciona e justifica a consecução da presente pesquisa para a realidade brasileira.

A presente proposta de trabalho está constituída de cinco seçóes, incluindo essa introdução e as considerações finais. A segunda seção discorre sobre o problema do pecado original doméstico. $\mathrm{Na}$ terceira seção será realizada uma discussão a respeito do cenário macroeconômico mais geral e do nível de endividamento do setor público ao longo do interregno avaliado, bem como uma investigação sobre as características e o comportamento dos títulos federais por indexador. Por fim, a quarta seção apresenta o método e as fontes de dados empregados no trabalho para os cálculos dos índices no que se refere à constatação da existência e da magnitude do pecado original doméstico no Brasil, além da análise dos resultados encontrado para o período em questão.

\section{Pecado original doméstico}

Eichengreen e Hausmann (1999) conceberam o conceito de pecado original (original sin) na sua dimensão doméstica como a incapacidade de um país emitir títulos de longo prazo da dívida no mercado interno, sobretudo, com base em prefixados. Os autores exploram o argumento de que essa incapacidade de aquisição de empréstimos em sua moeda nacional surge na maioria dos países em desenvolvimento, e gera uma situação em que os ativos estão denominados em moeda doméstica fraca, enquanto o passivo encontra-se denominado ou atrelado à moeda estrangeira forte, em função da estrutura piramidal da hierarquia das moedas. Esses autores exploram o argumento de que independentemente do regime de câmbio adotado, da qualidade das políticas econômicas e das instituiçóes estabelecidas em uma economia, essa incapacidade de aquisição de empréstimos em sua moeda nacional surge na maioria dos países em desenvolvimento.

Os agentes privados e públicos, geralmente, obtêm receitas denominadas em moeda local, mas em cenário marcado pela desvalorização cambial incorrem em maior dificuldade em saldarem suas dívidas denominadas ou vinculadas à moeda estrangeira. Caso o empréstimo seja de curto prazo, com vistas a financiar projetos de longo prazo, bastaria que os juros se elevassem para que os tomadores piorassem as suas condiçóes de saldarem a dívida contraída. Os agentes enfrentam o tradde-off tanto no que se refere à moeda escolhida (local ou estrangeira), quanto à natureza do empréstimo, que pode ser de curto ou longo prazo; disso decorre que qualquer financiamento está intrinsecamente sujeito a um descasamento da moeda (currency mismatches) ou a um descasamento dos prazos (maturity mismatches).

Portanto, na presença do pecado original as economias experimentam algumas disfunçóes macroeconômicas crônicas, que repercutem em um crítico descasamento de moedas no próprio balanço de pagamentos. Isso obriga as autoridades monetárias mitigarem 
esse problema por intermédio da acumulação de reservas cambiais e por um maior nível de juros de curto prazo. Adicionalmente, por apresentar parcela substancial da dívida pública indexada à moeda-chave e à taxas de juros, essas economias apresentarão maior nível de incerteza e menor rating de crédito soberano, além de parcela considerável da dívida interna indexada ao juros e baixa base de prefixados. Por saberem dos riscos associados à possibilidade de depreciaçáo cambial que dificultaria o pagamento de débitos por agentes internos, os investidores tendem a exigir maiores prêmios de riscos, o que reforça o caráter pró-cíclico do fluxo de capitais, dado que as taxas de câmbio tendem a experimentar apreciação em períodos de expansão cíclica e depreciação em períodos de reversão cíclica (EICHENGREEN, HAUSMANN, PANIZZA, 2005).

\section{Macroeconomia brasileira e a dívida pública federal mobiliária interna entre 2001 a 2016}

O primeiro Governo Lula inicia-se em 2003 com o compromisso de manter a estabilidade macroeconômica. Nesse sentido, dentre as medidas adotadas destaca-se a elevação do superávit primário, o crescimento da carga tributária e a manutenção das taxas de juros em níveis elevados (CASTRO et al., 2008). O ano de 2006 marca uma fase em que políticas austeras e de estabilização cedem lugar a um processo de franca expansão fiscal e monetária, bem como de valorização do salário mínimo. Conforme Mattos (2015), a busca pela ampliaçáo do consumo e dos postos de trabalho pode ser ilustrado pelos vultuosos investimentos públicos mobilizados pelo Programa de Aceleraçáo do Crescimento (PAC), e pelo crescimento tanto de famílias beneficiárias quanto dos valores reais em repasses previstos e executados nos programas de distribuição de renda. No ano de 2008, os efeitos da crise subprime sobre a economia global, sobretudo, com a quebra do Banco Lehman Brothers, também atingiram a economia brasileira. A estratégia adotada pelo Governo Federal para enfrentar a crise internacional foi de restringir o superávit primário, em prol de uma política expansiva com base na ampliação do Programa Bolsa Família, investimentos públicos, liquidez e crédito.

\subsection{A macroeconomia atual da dívida pública brasileira}

Entre os anos de 2003 a 2010, as contas externas do Brasil apresentaram resultados positivos, mesmo no contexto da crise financeira mundial de 2008. O balanço de pagamentos desse período registrou um superávit acumulado de US\$231, 8 bilhóes. Tal resultado permitiu que o País se tornasse independente dos empréstimos sistemáticos fornecidos pelo Fundo Monetário Internacional (FMI), além de possibilitar a redução do endividamento externo e um substancial acúmulo de reservas (CINTRA; ACIOLY, 2012). Conforme Teixeira e Pinto (2012), o cenário descrito acima foi viabilizado por um contexto internacional bastante favorável, em função do forte crescimento mundial verificado até 2008 , por conta da ampliação da liquidez nos mercados financeiros e dos preços favoráveis às commodities, sobretudo, impulsionado pelo efeito China. Grosso modo, o panorama econômico brasileiro pode ser evidenciado no Gráfico 1, cuja taxa de crescimento real apresenta alguma tendência de crescimento entre 2001 a 2008, em que 
pese sua irregularidade e forte retrocesso observado em 2009, em função dos efeitos da crise internacional, mas que se recupera nos dois anos subsequentes.

Gráfico 1 - Taxa Anual de Crescimento Real do PIB (2001-2015)

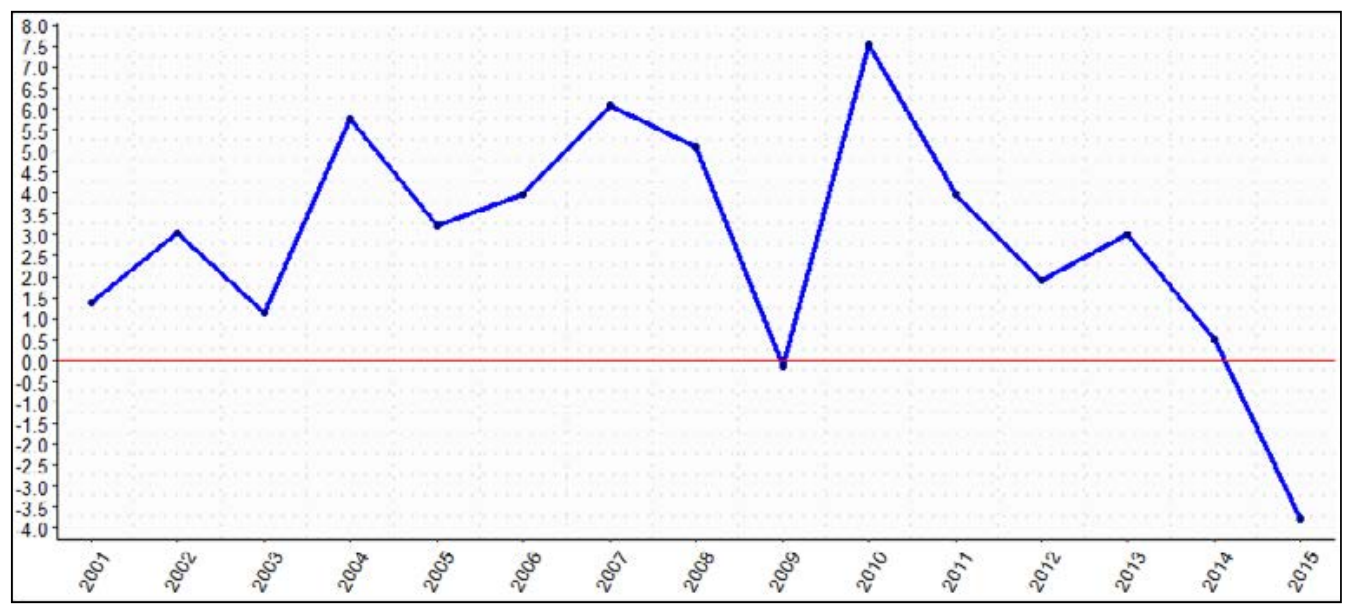

Fonte: Elaboração própria com base nos dados disponíveis no sistema DataBank do Banco Mundial.

O gráfico supracitado também evidencia que a partir de 2010 ocorre uma desaceleração da economia brasileira, cuja explicação certamente não está desassociada do comportamento da taxa de investimentos verificado a partir desse ano. Isso pode ser constatado ao se verificar que entre 2004 a 2010 a taxa média real dos investimentos no Brasil foi de 8,0\% a.a, enquanto que entre 2011 a 2014 essa variável náo ultrapassou 1,8\% a.a (MATTOS, 2015). Além disso, a desaceleração da economia chinesa, a reversão dos preços das commodities, o alto endividamento das famílias e a conjuntura mundial desfavorável estão entre os fatores elencados para explicar a deterioração da economia brasileira a partir de 2012, que agudizou ainda mais nos anos subsequentes. Destaca-se no Gráfico 1 que em 2014 o PIB real cresceu aproximadamente apenas $0,5 \%$, sendo que para os anos de 2015 e 2016 apresentaram uma redução de $3.77 \%$ e $3.60 \%$, respectivamente.

No que se refere aos impactos dessa dinâmica no nível de preços, percebe-se pelo Gráfico 2, que o Índice Geral de Preços do Mercado (IGP-M) e o Índice de Preços ao Consumidor Amplo (IPCA) demonstram comportamentos convergentes, a despeito dos movimentos do primeiro serem mais acentuadas pela natureza da sua forma de cálculo e amplitude dos itens que consideram na sua metodologia. Ambos se elevaram em 2001 e 2002, sendo um movimento bastante brusco no caso do IGP-M. Contudo, o IPCA declinou de $12,53 \%$ a.a em 2002 para 3,14\% a.a em 2006, enquanto o IGP-M cai vertiginosamente de $25,31 \%$ a.a para $1,21 \%$ a.a em 2005. A inflação no Brasil volta a acelerar até 2008, mas declina no ano subsequente e, em particular, com o IGP-M sendo negativo nesse ano. Nos anos posteriores houve uma tendência a certa estabilidade no IPCA em torno de 6\% a.a - com uma pressão de alta mais aguda em 2015. Por sua vez, o IGP-M demonstra um comportamento menos estável, mas com tendência de queda até 2014, seguido de uma drástica elevação no ano ulterior. Não se pode negligenciar que a inflação no final do 
período avaliado encontra-se em níveis superiores aos constatados no ano de 2001 para ambos os índices considerados (Gráfico 2).

Gráfico 2 - IPCA e IGP-M Anual

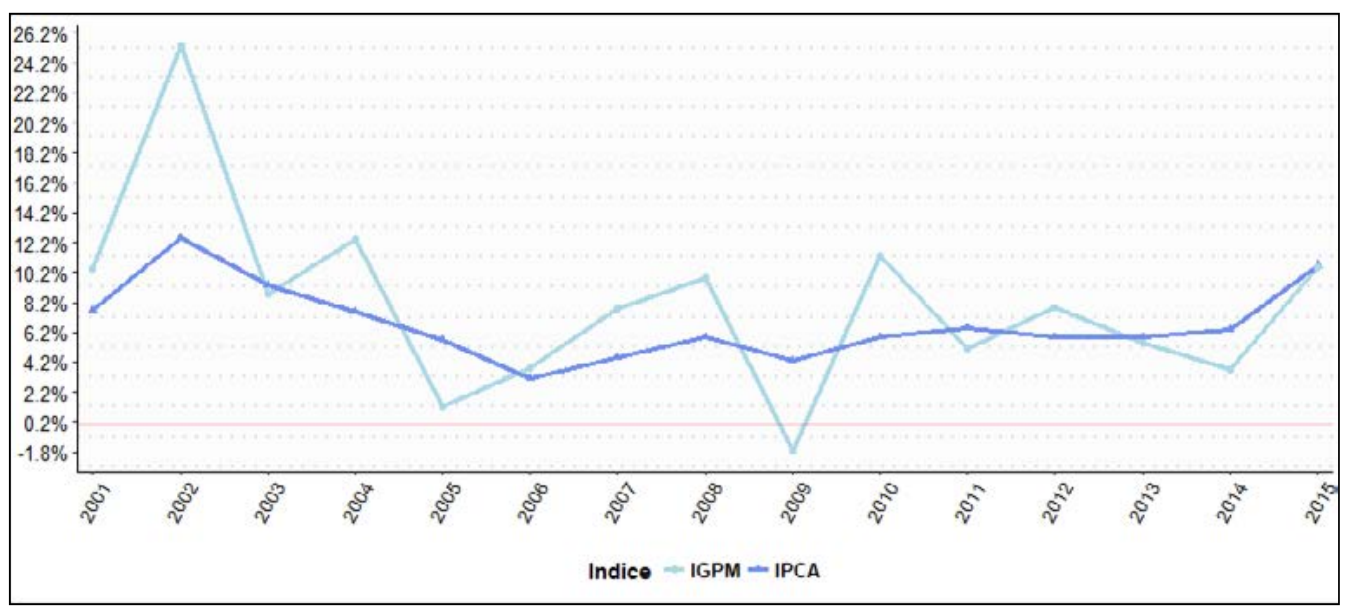

Fonte: Elaboração própria com base nos dados do IPEADATA.

Ao representar a média dos juros que o Governo paga aos bancos, a taxa de juros nominal Overnight/SELIC configura a taxa referencial básica para demais transaçóes financeiras da economia. Sobre essa taxa é possível verificar no Gráfico 3 um padrão errático e com tendência de declínio, a despeito dos seus níveis reconhecidamente altos para o padrão mundial ao longo de toda a série.

Gráfico 3 - Taxa Nominal Overnight SELIC/Mensal (2001-2016)

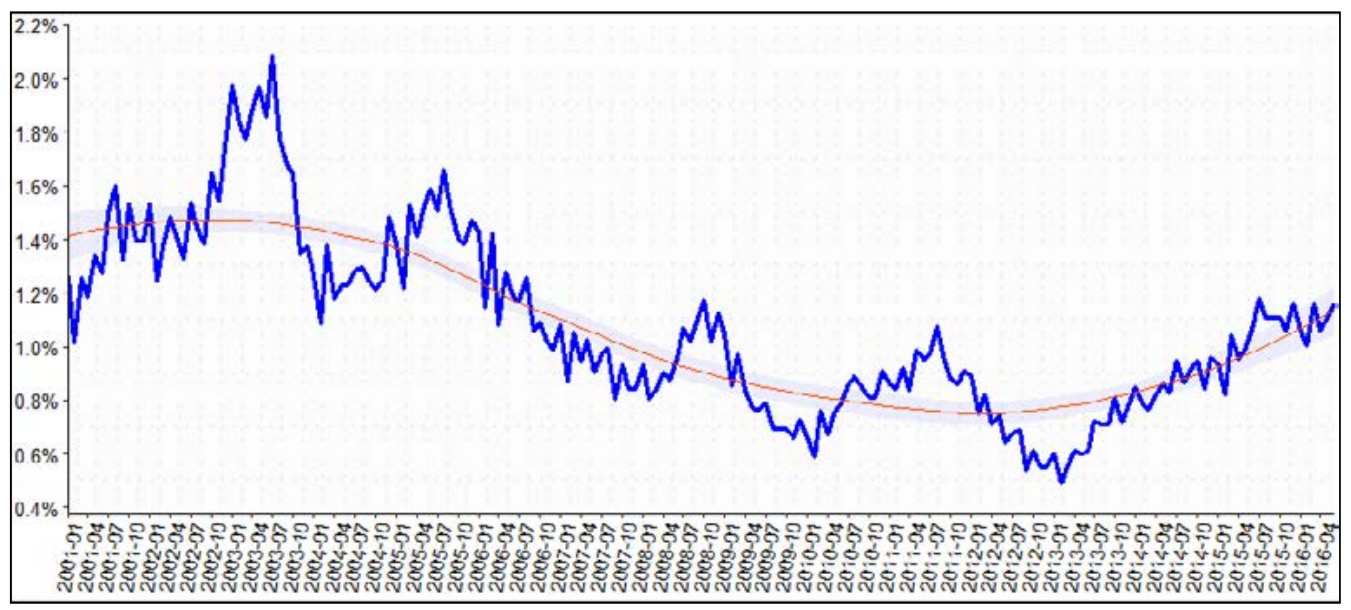

Fonte: Elaboração própria com base nos dados do IPEADATA.

Entre 2001 até parte de 2003, a SELIC apresentou padrão de crescimento, mas a partir de meados desse último ano apresentou tendência de queda, que persistiu até meados 
de 2010; em que pese às pressóes de alta observadas no ano de 2005, 2008 e início de 2009. A partir de 2013 a SELIC demonstra tendência de crescimento. No entanto, nos últimos cinco meses de 2015 e nos três primeiros de 2016, a taxa SELIC tem se mantido relativamente próximo do patamar observado nos primeiros meses do ano de 2001 . Essa dinâmica explicitada do nível macroeconômico, obviamente, também repercute sobre o endividamento e financiamento do setor público brasileiro, e esse quadro pode ser verificado no comportamento do resultado primário no período avultado, conforme o Gráfico 4 a seguir.

Gráfico 4 - Resultado Primário Anual Como \% PIB (2002-2015)

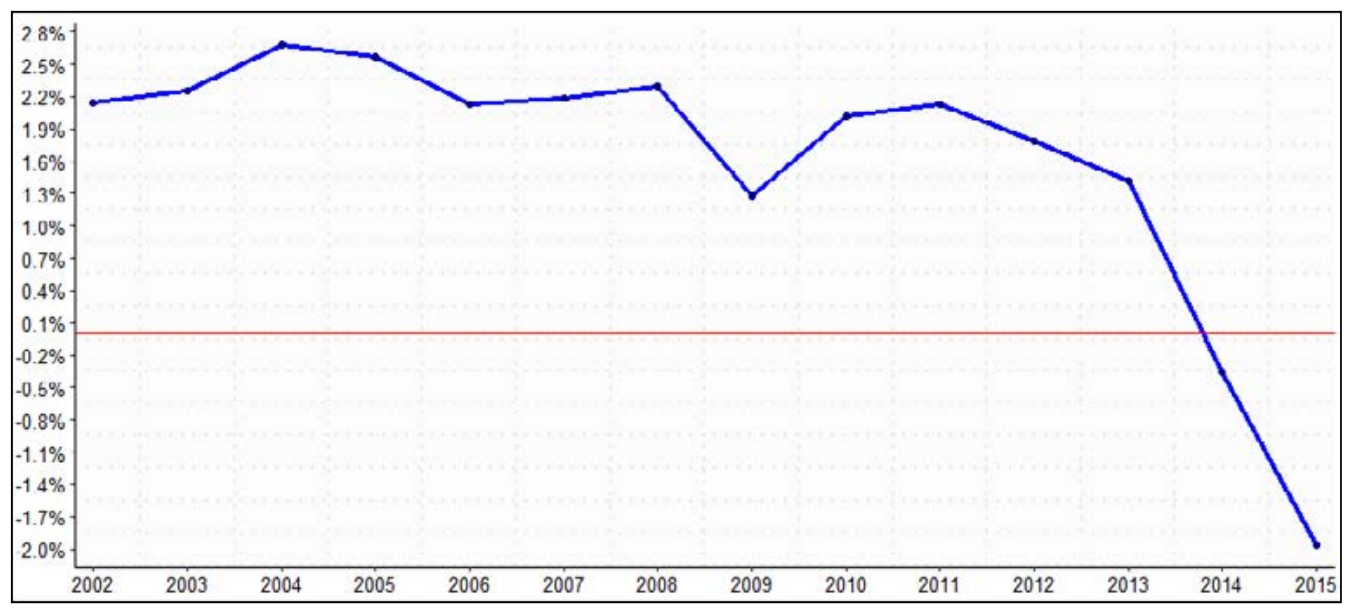

Fonte: Elaboração própria com base nos dados do IPEA.

Observa-se que até a deflagração da crise de 2008, o superávit primário mantém-se estável entre 3\% a 4\% do Produto Interno Bruto (PIB). Com os efeitos da crise em 2009 e retração da economia (Gráfico 01), há uma drástica queda no resultado das contas públicas, mas já no ano seguinte se esboça um movimento de recuperação até 2011; porém, não mais no mesmo nível verificado até 2008. No período entre 2012 a 2015 houve uma tendência de franca queda, sendo nesses dois últimos registrados um déficit no saldo primário.

Por sua vez, no Gráfico 5 apresenta-se a dívida bruta total, interna e a externa do setor público como proporção do PIB, em termos mensais entre fins de 2001 até junho de 2016. É possível perceber que a dívida pública bruta total e a sua parcela correspondente à dívida pública bruta interna apresentam valores críticos e comprometem consideravelmente a renda nacional. Identifica-se que, a partir dos últimos meses de 2002, a dívida bruta total inicia um processo de declínio, se estabilizando em torno de 60\% do PIB entre 2008 a 2014; sendo sucedida por uma forte tendência de elevação que impulsionou a dívida bruta para $73,2 \%$ do PIB no final da série. 
Gráfico 5 - Dívida Bruta Total, Dívida Bruta Interna e a Dívida Bruta Externa do Setor Público Mensal Entre 2001 a 2016 (\%PIB)

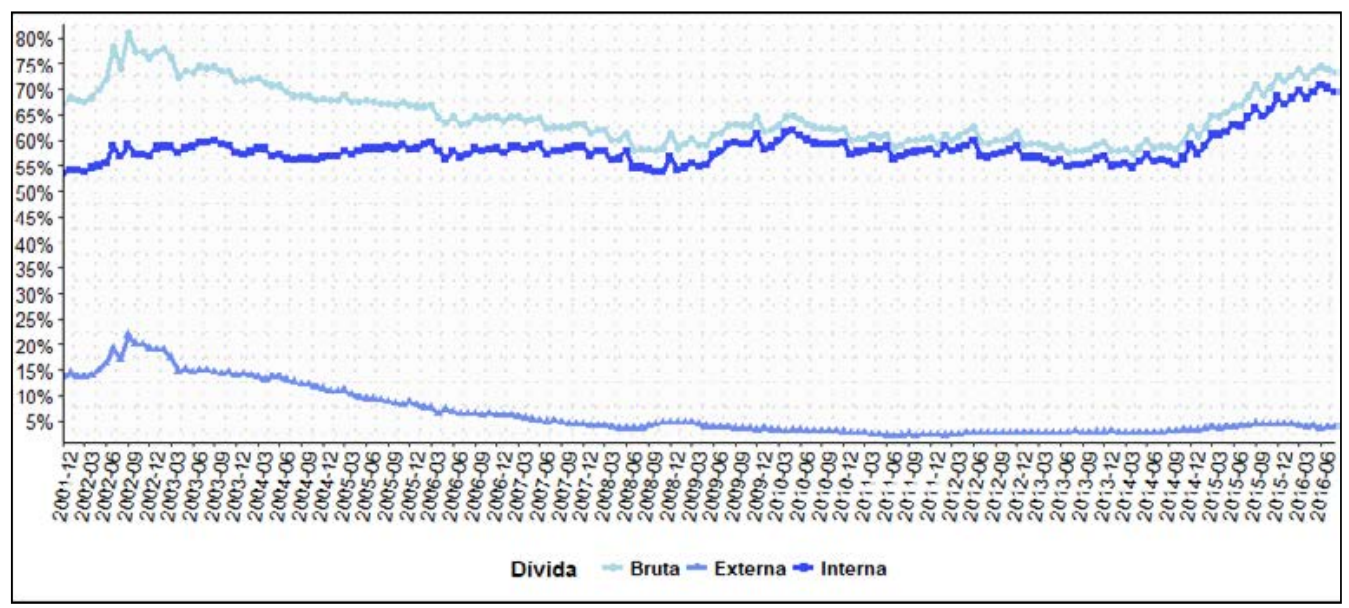

Fonte: Elaboração própria com base nos dados do Tesouro Nacional (STN).

A despeito da dívida externa bruta do setor público não ter ultrapassado $10 \%$ do produto interno, a partir de 2005 o comportamento da dívida bruta total foi praticamente dominado pelos movimentos da dívida interna bruta. Vale ainda ressaltar que a análise favorável sobre a dívida externa subdimensiona a sua dimensão total, dado que a dívida denominada em dólar de empresas e bancos privados brasileiros no exterior alcançou a impressionante cifra de US\$27 bilhóes, com vencimento até 2020 (BLOOMBERG, 2016).

O desempenho favorável da dívida externa bruta do setor público consolidado pode ser parcialmente explicado pela virtuosa ampliação do estoque de reservas internacionais ao longo do período, a despeito de ter se estagnado a partir de 2012; conforme pode ser apreciado pelos valores acumulados mensalmente em milhóes de dólares. $\mathrm{O}$ salto das reservas internacionais foi de US\$ 35 bilhóes em janeiro de 2001 para US\$ 375 bilhóes em março de 2016 (Gráfico 6); o que colocou o Brasil entre os dez maiores detentores mundiais de reservas, sendo decorrente do desempenho positivo da balança comercial em função dos preços favoráveis às commodities e do efeito China, bem como pela afluência de capitais atraídos pela manutenção de juros relativamente altos em cotejo com o resto do mundo. 


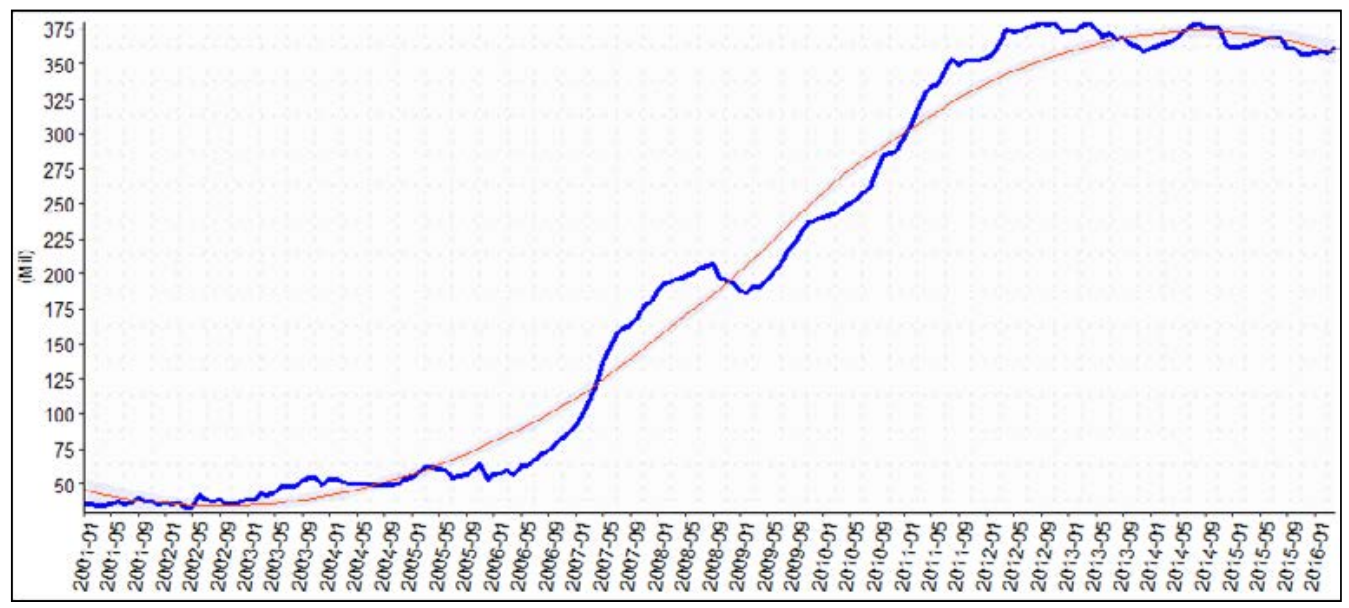

Fonte: Elaboração própria com base nos dados do Banco Central.

\subsection{Dívida pública mobiliária federal interna: indexadores, prazos médios e detentores}

O primeiro marco institucional no sentido de aprimorar a gestão do orçamento público, com fortes repercussóes positivas sobre a capacidade de endividamento do Governo Federal, pode ser identificado na implementação da Lei de Responsabilidade Fiscal (LRF), nos primeiros meses do ano 2000. Essa Lei representou o início do estabelecimento de uma série de medidas e mudanças nos marcos institucionais que objetivaram aumentar a transparência, controle e o acompanhamento da sociedade sobre a gestão dos orçamentos do Estado, além de impor limites aos déficits e à expansão do endividamento do setor público (LOPREATO, 2002).

Conforme Silva, Garrido e Carvalho (2009), o Governo Federal buscou desestimular o mercado mobiliário doméstico de indexados ao dólar e à taxa de juros de curto prazo a partir de 2002. Os títulos atrelados ao câmbio foram sendo praticamente extintos, enquanto se procedeu à paulatina substituição dos indexados à SELIC por emissóes prefixadas. Ademais, houve esforços no sentido de promover a expansão dos prazos de resgate dos títulos indexados à taxa de juros, como forma de pelo menos mitigar os impactos dessas emissóes sobre o gerenciamento da dívida pública, dada a importância que ainda cumpre na atração de investidores ao mercado mobiliário central. Pedras (2009) elucida que em 2006 o Governo Federal promulgou a Lei n. ${ }^{\circ} 11.312$, cuja finalidade consistia em estipular isençôes de Imposto de Renda sobre os ganhos de capital para investidores estrangeiros, com o objetivo de atraí-los para o mercado mobiliário interno e incentivá-los a adquirirem títulos que fossem não indexados ao câmbio e à SELIC, com prazos de maturação mais longos.

O Tesouro Nacional buscou concentrar os vencimentos das emissóes em datas específicas, além de implantar leilóes de compras antecipadas de títulos prefixados e de 
recompras dos indexados à inflação, com vistas a flexibilizar a capacidade dos adquirentes mudarem suas posiçóes e incentivá-los a demandarem esse tipo de emissão. Também se aprimorou o sistema de dealers com a criação de dois grupos de operação, a saber: i) o primário, responsáveis pela aquisição dos papéis nos leilóes públicos; ii) e os especialistas, responsáveis pelas transaçóes dos títulos nos mercados secundários (PEDRAS, 2009).

Os resultados dessas medidas estão explicitados a partir do Gráfico 7, que demonstra a participação dos títulos prefixados na composição da Dívida Pública Mobiliária Federal Interna (DPMFI) entre 2001 a 2016. Até meados de 2003, a parcela dos títulos prefixados declina vigorosamente. Esse período é sucedido por uma forte tendência de elevação da importância dos prefixados na dívida interna, que é interrompida com a crise de 2008; a despeito do impulso de crescimento da participação dos prefixados no montante da dívida mobiliária interna ter se recuperado em 2009, embora em ritmo inferior àquele observado antes da crise. Portanto, se em janeiro de 2001 esse tipo de título representava apenas $14,44 \%$ das emissóes internas, em março de 2016 correspondia a 38,58\%.

Gráfico 7 - Títulos Prefixados e Indexados (\% DPMFI) - Mensal

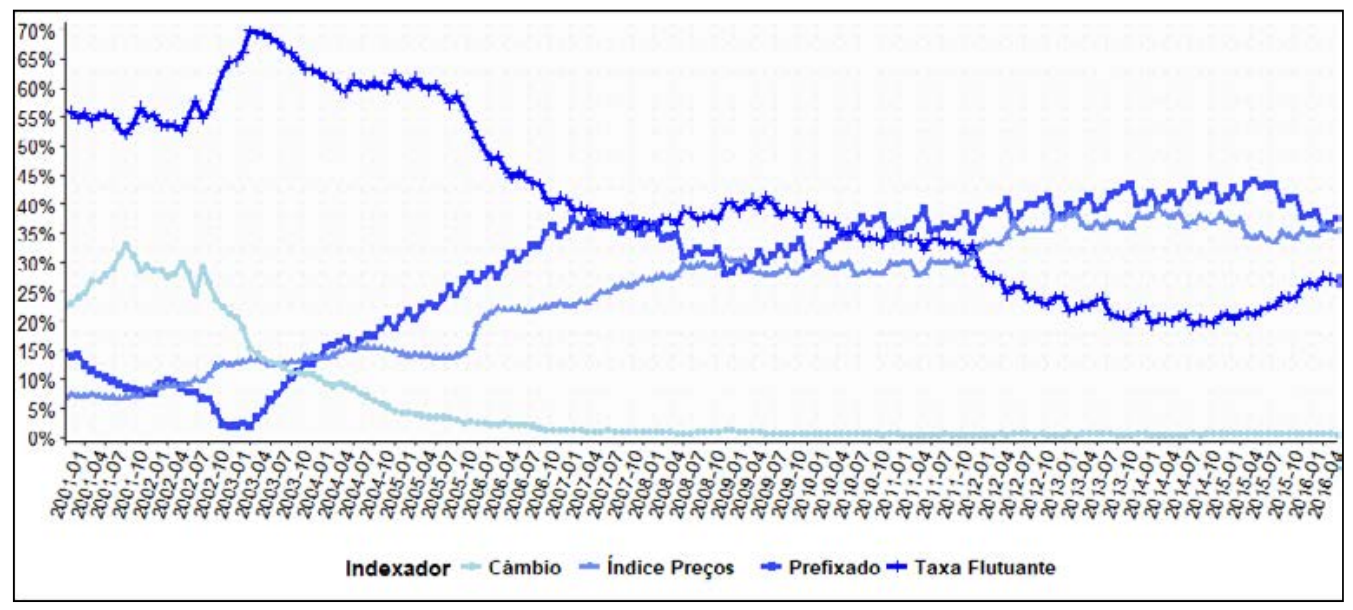

Fonte: Elaboração própria com base nos dados do Tesouro Nacional (STN).

Nota: A taxa flutuante se refere aos títulos indexados à taxa de juros.

Combinado a ampliação da base prefixada, talvez o maior avanço no perfil das emissóes internas tenha sido a praticamente extinção dos títulos indexados ao câmbio, que chegou a representar mais de $30 \%$ da dívida mobiliária doméstica em meados de 2001 , e a partir de 2008 já eram praticamente inexistentes na sua composição total (em média, menos de $0,5 \%$ ). É importante salientar que o Tesouro Nacional desde o início de 2002 deixou de emitir títulos indexados ao câmbio; em que pese a sua participação na composição total da dívida mobiliária interna ter se mantido relevante, mas em franco declínio até $2008 \mathrm{em}$ termos de importância. Portanto, o objetivo do Governo foi evitar novas emissóes indexadas ao dólar e, gradativamente, reduzir a sua participaçáo no montante a ser quitado do passivo.

Destarte, houve progresso do Governo Federal em ampliar a base da dívida mobiliária interna prefixada e extinguir os riscos atinentes às variaçóes cambiais da dívida interna. Mas, 
uma análise superficial sobre esse quadro pode superestimar tais resultados, uma vez que ao longo da série fica evidente que a maior parte da dívida interna é pós-indexada. Dentre os títulos pós-indexados o crescimento mais vertiginoso foram aqueles indexados a algum índice de preço, conforme demonstrado no Gráfico 7. Durante toda a série houve tendência de aumento da importância dessas emissóes; que foram de 6,92\% do DPMFI no início de 2001, estabiliza-se em torno de $30 \%$ em período pós crise de 2008 , e volta a se ampliar a partir de 2012, chegando a corresponder 34,68\% em março de 2016.

Em que pese o crescimento dos títulos indexados ao nível de preços constituírem uma deliberaçáo explícita do Governo Federal, não se pode ignorar o fato dessa estratégia denunciar a incapacidade do setor público manter um nível satisfatório de financiamento via mercado mobiliário interno, sem oferecer algum tipo de proteção contra as variaçóes no nível de preços. Isso pode ser devidamente compreendido quando se recupera a discussão empreendida no Gráfico 2, em que se apresentou o comportamento do nível de preços no Brasil medido pelos índices IPCA e IGP-M, e foi evidenciado que no final da série a inflação se manteve em um patamar próximo àquele verificado em seu início. É possível que a memória inflacionária decorrente dos problemas crônicos associados ao nível de preços, induza uma maior insegurança por parte do público brasileiro a esse tipo de investimento.

O grau de sucesso logrado pelo Governo Federal na estratégia de reduzir a vulnerabilidade das contas públicas indexadas à taxa de juros, em que pese a sua expressividade, não logrou o mesmo êxito observado no tratamento das emissóes cambiais, conforme se verifica no Gráfico 7. Identifica-se a partir de 2003 um movimento bastante expressivo de declínio da participação dos títulos indexados à taxa de juros na composiçáo da dívida mobiliária federal interna, saindo de 56,09\% em janeiro de 2001 para 26,13\% em março de 2016. Entretanto, é preciso considerar que uma dívida em que um quarto da sua composição está intrinsecamente vinculado à taxa de juros, ainda configura um quadro crítico para uma economia que pratica níveis de taxa de juros elevadíssimos para os padróes internacionais. Vale recordar que, na seção anterior, o Gráfico 3 mostrou que o declínio da SELIC entre 2003 e 2010, voltou a ser sucedido por um impulso de crescimento da taxa referencial; de modo que se em janeiro de 2001 seu valor era de 16,28\%, e em março de 2016 ainda se mantinha em torno de 14,15\%. Esse panorama é sintomático quanto aos riscos e custos para as contas públicas implicados numa parcela ainda expressiva do passivo interno atrelado à taxa de juros.

Portanto, evidencia-se algum êxito nas medidas implementadas com vistas a ampliar a base prefixada e indexada à inflação, simultâneo à redução dos indexados à taxa de juros e, precipuamente, ao câmbio. No entanto, é mister observar que a elevada importância apresentada pelos títulos atrelados à inflação nas suas emissóes, denuncia a dificuldade do setor público brasileiro de se financiar no mercado mobiliário interno sem oferecer, em contrapartida, algum mecanismo atrativo de segurança contra os riscos inflacionários. Ademais, ao se considerar que cerca de $30 \%$ da dívida soberana está indexada à taxa de juros e ao câmbio, observa-se que o governo brasileiro ainda não tem despertado um nível de confiança e credibilidade interna e externa que seja capaz de manter um perfil de financiamento que exclua os investidores com propensôes deletérias à solvência do passivo público. 
O problema se torna ainda mais agudo sob a ótica dos prazos médios e do tempo de maturidade dos títulos públicos federais. O Gráfico 8 demonstra os prazos médios em anos, distinguidos por indexador. Justamente os títulos que atualmente sáo praticamente irrelevantes, isto é, os títulos cambiais, foram os que historicamente apresentaram os prazos mais elásticos. Os títulos indexados à inflação desde o início da série apresentaram prazos médios próximos de seis anos, e tem alargado ainda mais o seu prazo médio, permanecendo em torno de oito anos. Isso sugere que a demanda por emissóes com prazos maiores perpassa pelo fornecimento de proteçōes contra os riscos decorrentes das variações cambiais e das variaçóes nos preços.

Gráfico 8 - Prazos Médios Por Indexador em Anos (\% DPMFI) - Mensal

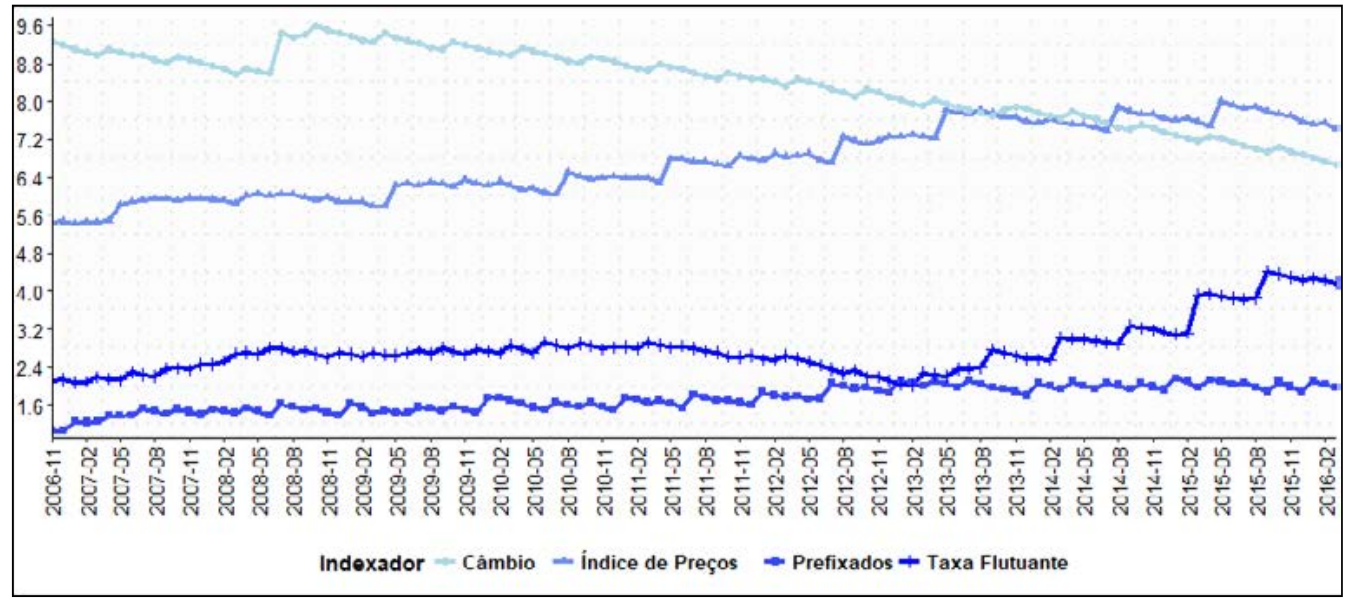

Fonte: Elaboração própria com base nos dados do Tesouro Nacional (STN).

Por sua vez, as emissóes internas indexadas à taxa de juros flutuante demonstram um perfil de prazos médios curtos, sendo de dois anos no início da série e de quatro anos no seu final. Nâo seria exagero definir o perfil dos demandantes por esse tipo de aplicação como propensos aos ganhos advindos de diferenciais de juros e de curto prazo. O desempenho mais crítico foi apresentado pelos títulos prefixados que ao final da série ainda se mantém em torno de dois anos em média. Portanto, a persistência dos baixos prazos médios dos títulos prefixados assinala a incipiência na confiança quanto à capacidade de solvência do Estado e do cenário macroeconômico nacional.

O panorama descrito sinaliza para os efeitos do grau de instabilidade do cenário macroeconômico do País face à crise econômica e política sobre os mecanismos de financiamento público, ao sinalizar uma deterioração da sua capacidade de solvência e perda de credibilidade junto aos investidores estrangeiros, que estão entre os principais detentores da dívida interna soberana do Brasil - conforme verificado no Gráfico 9, e que apresenta os detentores da dívida mobiliária interna federal entre janeiro de 2007 até janeiro de 2016. 


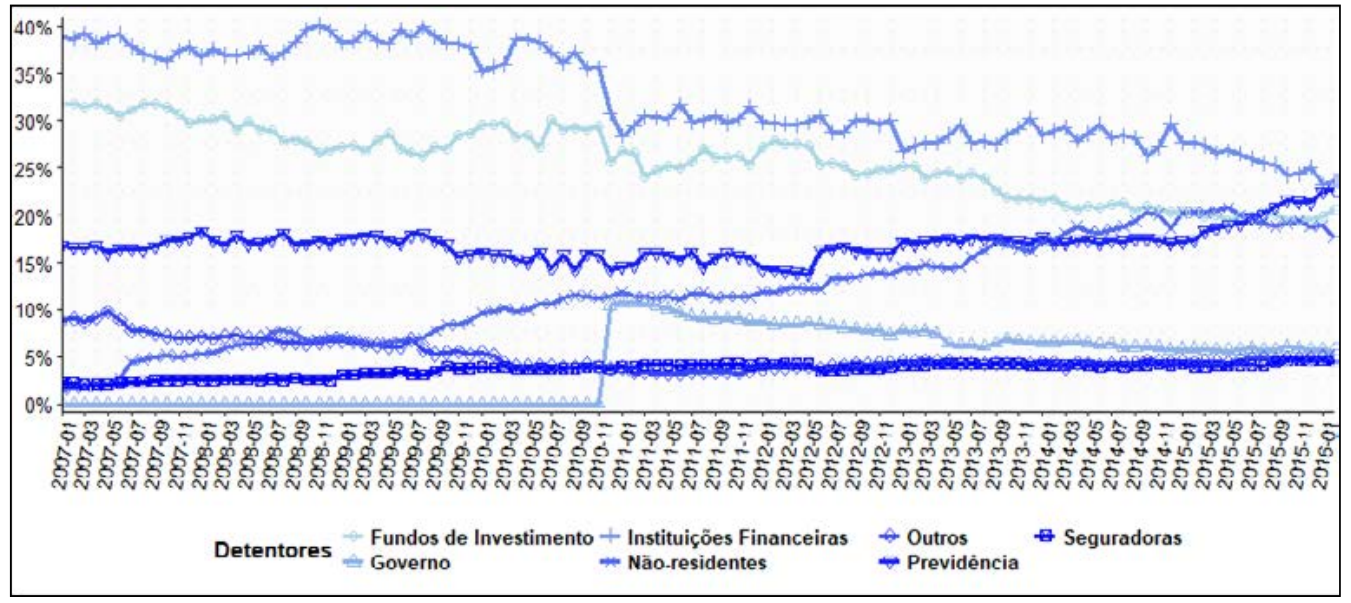

Fonte: Elaboração própria com base nos dados do Tesouro Nacional (STN)

É possível identificar que ao longo do período demonstrado pelo gráfico, as instituições financeiras ${ }^{7}$ são as principais credoras da dívida contraída pelo Governo Federal no mercado doméstico de títulos. O segundo maior detentor da dívida ao longo do período considerado foram os fundos de investimentos. Portanto, tanto as instituições financeiras quanto os fundos de investimentos, nitidamente, identificam as aplicaçóes garantidas pelo setor público como oportunidades vantajosas de ganhos pecuniários. Contudo, também se constata que as instituiçóes financeiras e os fundos de investimentos têm gradualmente perdido a primazia inconteste sobre a dívida soberana, em função do aumento do protagonismo das previdências e dos investidores não-residentes ${ }^{8}$ na lista dos principais detentores de títulos públicos; que inclusive, passaram a disputar pelas primeiras posiçóes a partir do ano de 2015. No caso dos investidores não-residentes a ascensão é ainda mais significativa, ao deterem apenas $1,55 \%$ dos títulos emitidos no mercado local em janeiro de 2007, e tornarem-se possuidores de 16,73\% dos mesmos em março de 2016.

As assertivas supracitadas estáo de acordo com os argumentos de Epstejn (2011), para o qual existe um movimento de deslocamento da demanda dos investidores estrangeiros por títulos públicos emitidos no mercado externo para os emitidos no mercado interno; ou seja, há uma propensão dos investidores estrangeiros em tornarem-se credores do governo brasileiro via mercado interno, em detrimento do mercado externo. A maior participação de investidores estrangeiros náo pode ser entendida como acidental ou contingencial, mas como uma estratégia deliberada do Governo Federal. Isso porque, conforme explicitado no início dessa seção, a Lei n. ${ }^{\circ} 11.312$ de 2006 preconizava isenções de Imposto de Renda

7 Corretoras, distribuidoras, estatais, BNDES, bem como bancos comerciais e de investimentos nacionais ou estrangeiros.

8 Inclui as pessoas físicas ou jurídicas e os fundos ou outras entidades de investimento coletivo com residência, sede ou domicílio no exterior. 
sobre os ganhos de capital para investidores estrangeiros, com o explícito objetivo de atraílos para o mercado mobiliário interno.

No Gráfico 9 também se observa a tentativa do próprio Governo de utilizar esse mercado para fins de política monetária, adquirindo algumas aplicaçóes mediante recursos administrados pela União (FAT ${ }^{9}, \mathrm{FGTS}^{10}$, fundos extramercados, fundos soberanos e garantidos) a partir de 2010, em que pese também ter perdido regularidade ao longo da série. Por fim, as seguradoras e a categoria denominada como "Outros" (constituída por residentes, sociedades de capitais, entre outros) configuram uma parcela menor, mas não ignorável da dívida interna.

\section{Metodologia e análise dos resultados: índices do pecado original doméstico e sua operacionalizaçáo}

O método utilizado para mensuração do pecado original doméstico (Domestic Original Sin - DSIN) será baseado no trabalho de Hausmann e Panizza (2003), sendo que esse conceito refere-se à incapacidade dos agentes das economias periféricas, especialmente o setor público, de emitir títulos de longo prazo no mercado interno, sobretudo, com base em títulos prefixados. Esses autores foram os responsáveis por formularem índices distintos para o cálculo da dimensão doméstica do pecado original, que formalmente consistem nas seguintes identidades:

$$
\begin{aligned}
& D S I N I I^{11}=\frac{F C+D S T F+D L T I I}{F C+D L T F+D S T F+D L T I I+D L T I P} \\
& D S I N I I I=\frac{F C+D S T F+D L T I I+D L T I P}{F C+D L T F+D S T F+D L T I I+D L T I P}
\end{aligned}
$$

Onde,

$F C^{12}=$ dívida em moeda estrangeira (foreign currency debt);

$D L T F=$ taxa fixa de longo prazo na moeda doméstica (long-term domestic currency fixed rate);

$D S T F$ = taxa fixa de curto prazo na moeda doméstica (short-term domestic currency fixed rate);

9 Fundo Amparo ao Trabalhador (FAT).

10 Fundo de Garantia do Tempo de Serviço (FGTS).

11 Ao longo do trabalho, adaptou-se esta metodologia no sentido de incluir no numerador também as emissóes de curto prazo dos indexados à inflação, uma vez que ao contrário do que ocorre em outros países, a totalidade das emissóes associadas à inflaçáo não são, necessariamente, de longo prazo. Logo, incluiu-se tanto o curto quanto longo prazo, dado que tal sistemática é compatível com a definição do conceito de pecado original.

12 Terminologias empregadas originalmente por Haumann e Panizza (2003). 
$D L T I I=$ taxa de curto prazo ou longo prazo na moeda doméstica indexada à taxa básica de juros da economia (long-term domestic currency debt indexed to interest rate);

DLTIP = taxa de longo prazo na moeda doméstica indexada a índices de preços (long-term domestic currency debt indexed to prices);

Conforme Hausmann e Panizza (2003), o DSIN II relaciona-se intrinsecamente com a dívida em moeda estrangeira, prefixados de curto prazo e com títulos indexados à taxa de juros locais. O DSIN II caracteriza-se por incorporar na sua análise: i) o grau de vulnerabilidade das emissóes de curto prazo, ainda que à taxa fixa; ii) e a exposiçáo à mudanças na taxa de juros de curto e longo prazo. Após calcular o indicador DSIN II, é possível comparar diagnosticar se o problema do pecado original doméstico, cujo valor obtido seja próximo ou igual à unidade, reside na parcela da dívida atrelada ao câmbio ou à taxa de juros, ou mesmo na parcela que não possui a característica desejável de ter longa maturidade, mesmo sendo prefixada.

Por sua vez, o DSIN III mensura a incapacidade das economias em endividarem-se no longo prazo a taxas prefixadas. Quanto mais próximo estiver o DSIN III da unidade, maior será a proporção da dívida atrelada à taxa de câmbio, aos juros pós-fixado e à inflação. $\mathrm{O}$ DSIN III constitui-se um índice mais completo e rigoroso do que o DSIN II, dado que nele se considera toda a parcela da dívida indexada à moeda estrangeira forte no quantum total dos valores das emissōes, e toda forma não previamente definida de indexação da dívida. O DSIN III unitário revela o nível máximo de pecado original interno, ao passo que um valor próximo de zero ou nulo somente ocorreria caso a economia avaliada demonstre um cenário considerado pela literatura como de maior solvência, além de satisfatória viabilidade e gerenciamento; ou seja, predominantemente denominada em moeda local, prefixada e de longo prazo. Em suma, o pecado original doméstico, por definição, somente poderá ser medido em sua completude mediante DSIN III, embora os índices anteriores colaborem na comparação e identificação da fonte do problema.

Os títulos públicos emitidos são divididos em cinco categorias distintas, para o cálculo da dimensão doméstica do pecado original. O primeiro consiste na DLTF, que representa os títulos prefixados de longo prazo denominados em moeda local; a totalidade das emissóes nessa categoria consistiria em um panorama extremamente favorável para a solvência da dívida pública mobiliária. O segundo corresponde ao $D S T F$, que são títulos prefixados de curto prazo também denominados em moeda nacional. $\mathrm{O}$ terceiro corresponde ao DLTII, que configura os títulos indexados à taxa de juros no curto ou longo prazo em moeda doméstica. A categoria representada por DLTIP refere-se aos títulos de longo prazo indexados a um índice de preço. Uma presença muito elevada da DLTIP indica uma dívida fortemente atrelada à inflaçáo, e pode colaborar para a persistência do aumento do nível de preços na economia e/ou mesmo no mercado de trabalho. Destaca-se ainda a dimensão $F C$, nessa categoria são consideradas as emissóes de títulos da dívida em moeda estrangeira. Quando a composição da dívida é dominada pela presença da categoria $F C$, os títulos emitidos no mercado local estariam predominantemente atrelados à moeda estrangeira, cuja consequência imediata consistiria na elevação dos riscos de liquidez e de descasamento da moeda. 
Mehl e Reynard (2005) corroboram com as assertivas supracitadas ao defenderem que uma substancial parcela da dívida atrelada ao câmbio, à inflação ou à moeda estrangeira forte, aumenta o risco de insolvência da dívida em períodos de crise e recessão. Além disso, um endividamento excessivamente de curto prazo impóe limites à autonomia nacional, no sentido de inviabilizar a adoção de certas medidas e políticas econômicas, a fim de combater à inflação ou à volatilidade e os riscos cambiais, dentre outros problemas. Em condiçóes limites, um panorama favorável a melhor solvência da dívida pública mobiliária deve ser majoritariamente prefixada, denominada em moeda nacional e de longo prazo. Essas características quando combinadas levariam a níveis nulos de pecado original doméstico na economia avaliada. Diametralmente, quanto mais grave for o pecado original doméstico, maior será a dependência da economia em relação às dívidas de curto prazo, cujas consequências expóem os mutuários aos riscos de inadimplência, quando de conjunturas que impliquem em elevaçáo do serviço da dívida e na incapacidade de arrolá-la.

Magnitudes extremas do pecado original doméstico constitui uma evidência contundente da inexistência de um mercado de títulos bem desenvolvido, bem como a carência de emissóes prefixadas com considerável maturidade. Quando os índices demonstrados apresentam valores próximos da unidade, tem-se uma economia fundamentalmente exposta às flutuaçóes de curto prazo, dado que os empréstimos contraídos apresentam pelo menos uma das três características deletérias, a saber: serem de curto prazo, denominados em moeda estrangeira ou atrelados a algum tipo de taxa volátil.

No presente estudo, o critério estabelecido para definir o período considerado como de curto ou longo prazo obedeceu à proposição defendida por Koller, Goedhart e Vesseels (2005), cujo trabalho explicita que o mercado de títulos norte-americano considera um período de resgate igual ou superior a dez anos como de longo prazo e com riscos mínimos. Souza (2015) também corrobora que o mercado de títulos público norte-americano define os títulos prefixados acima de dez anos como àqueles que representam melhor gerência quanto aos prazos. Benvenho (2011) reverbera esse mesmo argumento ao explanar que o mercado alemáo também define o tempo igual ou superior a dez anos como de longo prazo. Portanto, optou-se por tomar como referência o critério estipulado nessas economias referenciadas como exemplos de desenvolvimento social e econômico, sendo caracterizadas pela substancial maturidade do seu mercado financeiro. Deste modo, foi considerado como curto prazo apenas os títulos com prazos inferiores a dez anos. Por exclusão, os títulos com prazo de resgate igual ou acima de dez anos foram definidos como de longo prazo.

Os dados utilizados estáo disponíveis nos terminais da Secretaria do Tesouro Nacional (STN) e foram baseados no "Relatório Mensal da Dívida Pública Federal (DPF) ", divulgado pela Secretaria do Tesouro Nacional (STN). Também foram utilizados os dados do "Histórico de Leilóes do Tesouro Nacional", onde estáo elencadas as emissões diárias realizadas pela instituição. Foi considerado o universo de títulos da dívida emitida ou liquidada no mercado financeiro interno em funçấo do nível de captação total. Os dados referentes aos tipos de títulos foram desagregados em quatro categorias distintas, com base na forma de indexação apresentada por cada emissão, a saber: dívida atrelada ao câmbio, dívida prefixada, dívida atrelada à SELIC e a dívida indexada ao nível de preços; com diferentes prazos de vencimento, classificação de ratings e formas de colaterais. 
Para tanto, considerou-se a totalidade das emissóes do Governo Federal no mercado mobiliário brasileiro. Dentre os quais, encontram-se as Letras Financeiras do Tesouro (LFT), que são títulos com rentabilidade diária vinculada à taxa de juros básica, cujo valor de face ocorre na data vencimento dos títulos indexados à taxa SELIC, registrada entre a data de liquidação da aquisição e do resgate com ágio e deságio no momento da compra. O LFT possui fluxo simples, no sentido de que o investidor apenas recebe o valor de face na data do vencimento do título. Há também as Notas do Tesouro Nacional - Série C (NTN-C), com juros semestrais que são indexados ao IGP-M ${ }^{13}$, acrescido de juros na aquisição. Além de pagar cupom semestral de juros, o investidor ainda recebe o valor de face no resgaste. No presente trabalho, esses títulos foram considerados até 2006, dado que a partir desse ano eles deixaram de ser emitidos pelo Tesouro Nacional. As Notas do Tesouro Nacional - Série B (NTN-B) são títulos caracterizados por gerar rentabilidade associada ao índice IPCA ${ }^{14}$, acrescido de juros definidos no momento da compra. Por fim, foi considerado as Notas do Tesouro nacional - Série D (NTN-D), vinculadas aos movimentos cambiais. Essas classes de títulos compóem o grupo de pós-fixados, dado que são atrelados a algum tipo indexador.

Os títulos prefixados públicos são caracterizados por apresentarem rentabilidade definida no momento da aquisição, quais sejam: a Letra do Tesouro Nacional (LTN) e a Nota do Tesouro Nacional - Série F (NTN-F). A LTN apresenta um fluxo de pagamentos simples, de modo que o valor de face apenas é resgatado na data de vencimento do título. Diferentemente, a NTN-F é caracterizada por pagar cupons de juros semestrais, somado ao valor de face quando do vencimento da aplicação. Os títulos prefixados fornecem ganhos pré-definidos, e não possuem qualquer forma de indexação.

\subsection{Análise dos resultados: dsin ii, dsin iii}

A estratégia de calcular os dois índices supracitados, ao invés de apenas o DSIN III, consiste na possibilidade adicional de identificar qual o tipo de indexação que mais contribui para o pecado original doméstico. Além disso, mediante atribuição de valores numéricos é possível comparar os resultados entre os índices e ter-se alguma noção da gravidade causada pelos indexadores. Conforme o Gráfico 1 e em discussão anteriormente empreendida, demonstrou-se que os últimos anos de FHC e o primeiro Governo Lula possuem em comum a ênfase na estabilidade macroeconômica, enquanto o segundo mandato de Lula denota maior dinamismo e impulso ao crescimento econômico, distribuição de renda e benefícios líquidos do comércio exterior. A partir de 2011 evidencia-se um processo de desaceleração da economia brasileira, reversão dos preços das commodities e deterioração de algumas das suas principais variáveis macroeconômicas nacionais.

Dado que o Tesouro Nacional desde o início de 2002 deixou de emitir títulos indexados ao câmbio, torna-se evidente que o pecado original doméstico exclusivamente atrelado à moeda estrangeira forte passou a ser inexistente a partir desse período; o que

13 Índice Geral de Preços do Mercado (IGP-M).

14 Índice Nacional de Preços ao Consumidor Amplo (IPCA). 
denota a eficácia da estratégia do setor público em reduzir a dependência da DPMFI às flutuaçóes da moeda americana. Portanto, ao descartar a indexação cambial como principal forma de indexação dos títulos públicos brasileiros, torna-se fundamental voltar o foco da análise para a participação da indexação mediante índices de preços e taxa de juros.

O nível de pecado original medido pelo DSIN II é unitário até setembro de 2003 , sendo essa a razão pela qual o Gráfico 10 se inicia a partir desse ano. Os resultados encontrados pelo DSIN II para economia brasileira são em virtude de os títulos estarem vinculados à taxa de juros e aos prefixados de curto prazo. Os valores encontrados do DSIN II são corroborados pelas mudanças no perfil da composiçáo da DPMFI no subperíodo de 2002 a 2006, conforme apresentado na Seçáo 3. Naquela oportunidade, demonstrou-se que a parcela indexada à taxa de juros se manteve sempre acima de $40 \%$ da dívida mobiliária interna total nesse período, e a emissão de títulos prefixados cresceu significativamente, mas se caracterizaram por serem de curto prazo.

Gráfico 10 - Resultados do Índice DSIN II Mensal (2003-2016)

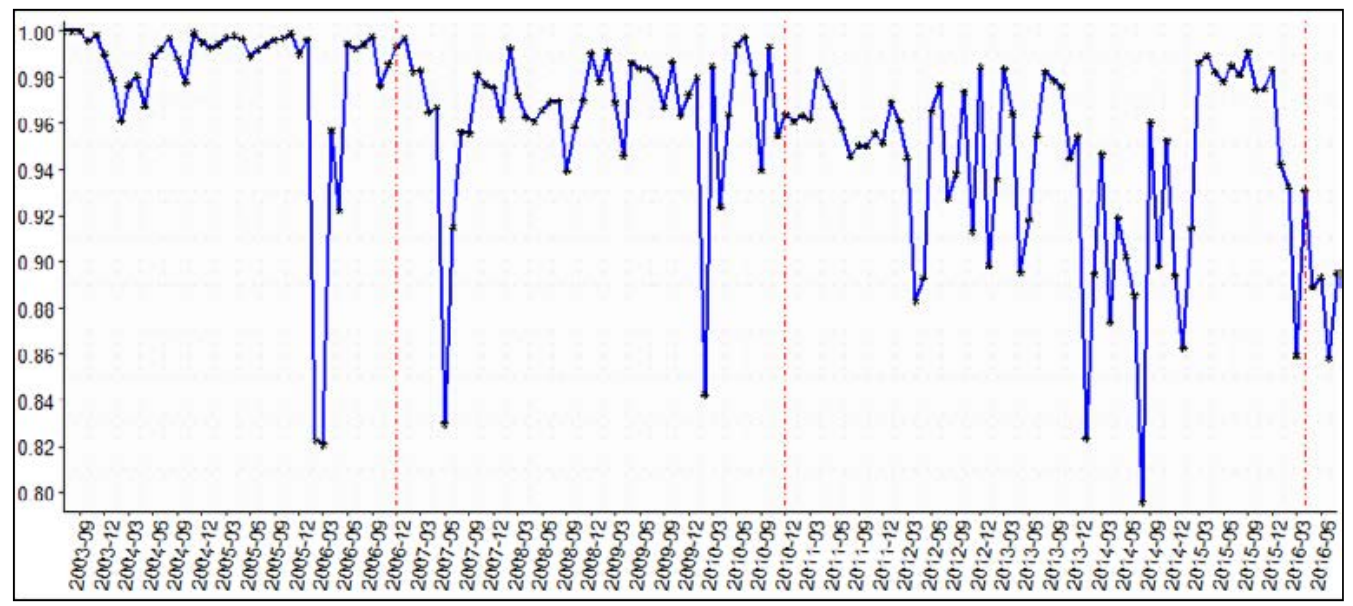

Fonte: Elaboração própria com base nos dados da pesquisa.

O índice DSIN III é apresentado no Gráfico 11, sendo o mais completo por considerar os prefixados de curto prazo, os indexados ao câmbio e à taxa de juros flutuante, bem como ao nível de preços ${ }^{15}$. A análise do subperíodo compreendido entre 2001 a 2006 revela a ocorrência da unidade ${ }^{16} \mathrm{em}$ todos os meses dos respectivos anos, dado que náo houve nenhuma emissáo ao longo de todo esse período que cumprisse, simultaneamente,

15 Desagregando em curto e longo prazo já considerando a tendência mundial de maiores prazos para títulos indexados à inflaçáo, mas que ainda configurariam um perfil a ser evitado (Hausmann; Panizza, 2003).

16 Destaca-se que como houve o índice apresenta o valor constante e igual desde o início da série até janeiro de 2014, optou-se por não apresentar de forma gráfica a partir do final de 2013, com vistas a destacar o seu comportamento após esse período. 
os critérios de serem: i) denominado em moeda doméstica; ii) ser prefixada; iii) e de longo prazo.

Gráfico 11 - Resultados do Índice DSIN III Mensal (2013-2016)

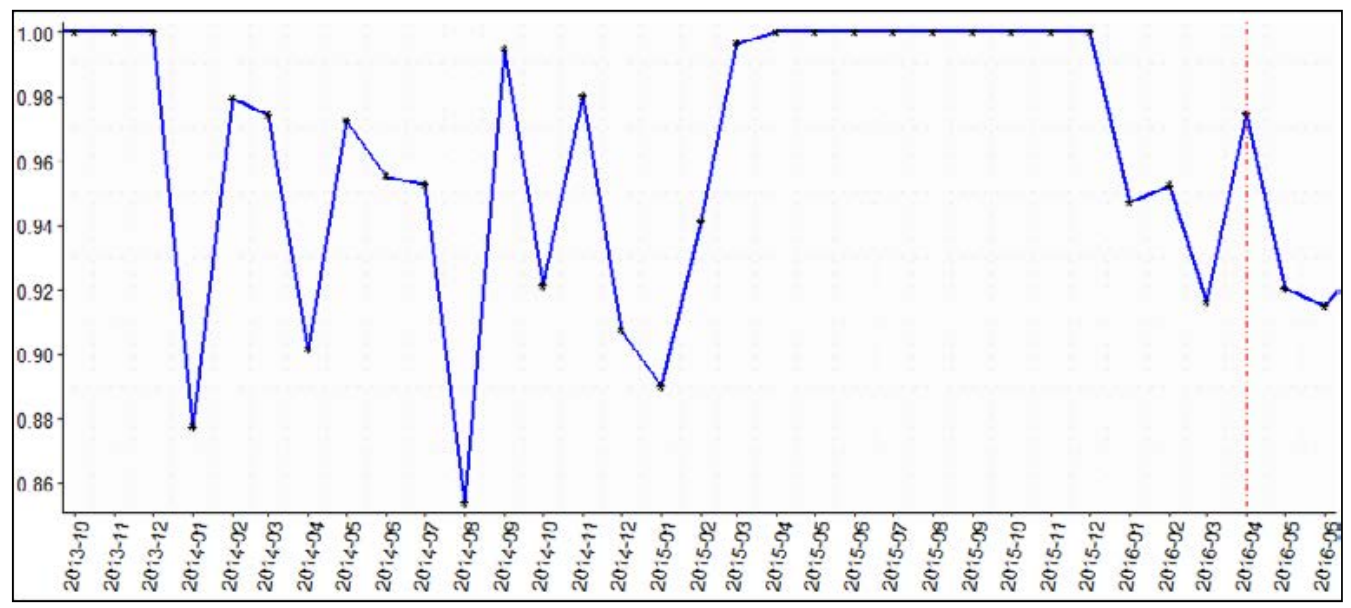

Fonte: Elaboração própria com base nos dados da pesquisa.

Em que pese ser integralmente denominado em moeda brasileira, o crescimento da parcela prefixada não foi superior à parcela pós-indexada, e tampouco representou a totalidade da dívida mobiliária interna; além de apresentar prazos de maturidade bastante distantes daqueles que podem ser considerados de longo prazo. Junta-se a isso, o fato da taxa de juros também apresentar caráter curto "prazista", sendo os indexados à inflaçáo os únicos com prazos de maturidade mais longos. Os resultados sistemáticos e contínuos não abrem espaços para dúvidas quanto ao problema do pecado original doméstico ter se manifestado em sua plenitude, e sem qualquer alteração substancial em sua magnitude nesse período histórico.

Uma vez que tanto o DSINII quanto o DSINIII foram próximos da unidade fica nítido que o crescimento dos prefixados de curtíssimo prazo, aliado a um crescimento vigoroso dos títulos indexados à inflação, bem como a participação persistentemente considerável dos indexados aos juros flutuantes, tornaram a capacidade e a qualidade da emissáo do setor público brasileiro longe do padrão sugerido pela literatura para ser caracterizado pela ausência de pecado interno. É nesse subperíodo que a importância das emissóes indexadas ao câmbio e da sua representatividade no total da DPMFI são basicamente eliminadas. Contudo, o crescimento dos prefixados de curto prazo, juntamente com os títulos associados à inflação, bem como a persistência das indexaçóes à SELIC, revelam que o pecado original interno não foi eliminado ou reduzido ao longo desses anos, mas apenas mudou de forma.

O DSIN II permanece em níveis elevados, mas o subperíodo apresenta dois meses consecutivos (maio e junho de 2007) em que se acusa um início de redução do pecado, embora isso não se mantenha de forma consistente no restante da série. Disso resulta que, longe de qualquer transformação substancial em relação à tendência demonstrada pelo índice no subperíodo anterior, as emissóes de prefixados de curto prazo, e a participação dos títulos 
indexados à taxa de juros em torno de $40 \%$ da DPMFI, revelam a incapacidade do setor público, também manifestada nos anos entre 2006 a 2010, de substituir os indexados por prefixados de longo prazo denominados em moeda local. Todavia, o movimento supracitado foi bastante tímido e sem grandes repercussóes no endividamento mobiliário federal interno. O panorama descrito está relacionado ao fato do ano de 2010 ter correspondido ao maior volume de vendas prefixadas desde 2003, com elevação significativa dos LTNS's. As emissóes da dívida com prazos acima de cinco anos constituíram 27,56\% do montante total nesse ano, inclusive, com alguma participação ínfima de prefixados de longo prazo (STN, 2015).

Por conseguinte, entre 2006 a 2010 o pecado original interno da economia brasileira não mostrou mudanças sensíveis em relação aos anos anteriores em termos quantitativos, a despeito da sua transformação qualitativa. O fato é que a década de 2000 findou sem qualquer mudança sensível quantos às conclusóes proferidas por Hausmann e Panizza (2003), que incluíram o Brasil no grupo composto pelos grandes detentores de pecado original interno no globo. Com base nesses resultados, verifica-se que a estratégia de transmutar o problema da dívida interna processada ao longo do decênio de 2000, na expectativa de lograr melhores resultados e controle sobre o perfil das emissóes, foi uma opção cujas dificuldades deixam — na melhor das hipóteses — uma interrogação quanto à sua efetividade e eficácia.

Em contraste com o cenário macroeconômico brasileiro, que passa a experimentar um momento crítico e difícil ao longo dos anos entre 2011 a 2017, marcando um processo de ruptura com a dinâmica favorável apresentada até então, os valores dos índices DSIN II e DSIN III nesse interregno parecem sugerir uma continuidade com a tendência esboçada em 2010; embora tal comportamento seja volátil e instável. Dado que o DSIN III mede o pecado doméstico de maneira mais rigorosa e completa, esse índice tende a acompanhar em alguma medida os movimentos do DSIN II, a despeito dos seus valores serem normalmente maiores. Ainda na Tabela 2 em anexo e o Gráfico 11, verifica-se que desde o início da série até o ano de 2013 o índice DSIN III mantém-se unitário em todos os meses. No ano subsequente, os valores são suavizados e demonstram uma perda de severidade, no sentido de apontar para a existência de emissóes livres do pecado interno, mais especificamente, com um ponto de mínimo ao longo de toda a série (com valor de 0,85 ).

Em síntese, o quadro da economia brasileira demonstrado entre 2001 a 2016 permite inferir que até 2009 houve a quase extinção das emissóes cambiais, que resultou na eliminação desse indexador como a forma pelo qual se manifesta o pecado interno brasileiro, além de marcar valores notavelmente críticos e limítrofes para o DSIN II e DSIN III; o que comprova de modo cabal a tímida existência de emissóes que fossem, simultaneamente, prefixadas de longo prazo e denominadas em moeda local. Esse resultado demostrou-se em total acordo com os aqueles evidenciados para recortes temporais distintos nos trabalhos de Hausmann e Panizza (2003) e Gomes et.al (2007).

O fato é que o pecado original interno é uma realidade ao longo de todo o período avaliado, e permite propositar que essa disfunção, longe de constituir-se uma falácia, uma mera hipótese ou categoria abstrata teórica sem qualquer conexão com a realidade, representa um fato concreto e historicamente caracterizador da economia brasileira. Não 
seria exagero definir esse fenômeno como um problema de ordem, basicamente, estrutural enfrentado pelos agentes nacionais e, em particular, pelo setor público - quando do acesso ao mercado financeiro com o propósito de mobilizar recursos. Os anos iniciais do período estudado sugerem que a forma do pecado interno brasileiro baseado no câmbio e na taxa de juros fora metamorfoseado, de modo a praticamente eliminar o primeiro tipo de emissão, mantendo uma parcela considerável da segunda. Mais precisamente, a eliminação das indexaçóes cambiais foi compensada pelo aumento vertiginoso da participação dos indexados ao nível de preços, juntamente com os prefixados de baixa maturidade, somado à manutenção da importância dos indexados à SELIC na composição total da dívida interna, sem que a magnitude do pecado original fosse substancialmente revertida em função disso.

O pecado original brasileiro manteve-se ao longo do período sem mudanças significativas e em níveis elevadíssimos, com alguma sinalização de reduçáo a partir de 2010, mas com contornos bastante marginais. O que realmente mudou ao longo do período considerado foi a forma do pecado interno. Se antes de 2002 o pecado original interno manifestava-se primordialmente mediante emissóes indexadas ao câmbio e aos juros, após esse ano o pecado interno se torna função dos indexados à inflação, dos prefixados de curto prazo e dos indexados à SELIC. Em outros termos, o problema do pecado original mudou de forma, mas não de gravidade. Além disso, o alto nível de indexação que caracteriza o mercado de títulos internos mantém-se predominantemente ao longo do período. Uma vez que se comprovou a existência do pecado original interno e demonstrou-se a sua metamorfose é possível identificar que não é a forma do pecado que lhe assegura a sua magnitude, mas sim, o fato de ser vinculado a um indexador de curto prazo.

A rigor, no caso brasileiro, uma mudança paradigmática da realidade descrita envolve uma reavaliação da estratégia adotada ao longo da década de 2000. Conforme demonstrado na Seção 03, não somente a parcela prefixada da dívida interna brasileira é inferior à indexada, como possui prazos de maturidade em torno de apenas dois anos. Nesse contexto, o Governo Federal procurou se financiar mediante mercado mobiliário eliminando os riscos cambiais, sobretudo, a partir do aumento da parcela indexada ao nível de preços. É provável que tal medida tenha sido parcialmente baseada no relativo controle da inflaçáo logrado no País em determinados anos do decênio. No entanto, essa taxa não somente se manteve em um nível incômodo em parte do período avaliado, como também se deteriorou a partir de 2014.

Em suma, o cenário político e econômico brasileiro no período pós-2010, e o retorno da taxa de juros e da inflação aos níveis próximos daqueles observados no início da década de 2000, assinala que tal estratégia resultou em consideráveis riscos e custos ao orçamento público federal. Disso decorre que a estratégia de apoiar o endividamento interno brasileiro em emissóes indexadas aos níveis de preços, numa perspectiva de longo prazo, deve ceder lugar à busca pela desindexação total das emissōes nacionais no mercado interno. Portanto, a atenuação do pecado original doméstico brasileiro por intermédio de paliativos, como a indexação à inflação, apenas modifica a forma pelo qual o problema se manifesta, ao invés de reduzir a sua magnitude. Isso evidencia a necessidade de se promover esforços de longo prazo no sentido de atenuar as indexaçóes aos índices de preços e à SELIC, em concomitância com a ampliaçáo da parcela prefixada de longo prazo da dívida. 


\section{Consideraçóes finais}

Ao longo do presente trabalho evidenciou-se que o sistema monetário internacional, longe de corresponder a uma configuração a-histórica ou advinda de alguma lei "natural", deve ser entendida como a resultante direta do confronto de interesses nacionais e das contingências históricas experimentadas pelas distintas economias nacionais. Nesse sentido, as consequências estruturais decorrentes da forma de inserção de cada economia nacional no âmbito do SMI implicam em distintos níveis de autonomia e capacidade de articulação de políticas macroeconômicas internas.

Dentre as consequências que decorrem da hierarquia das moedas no contexto do SMI, destaca-se o fenômeno do pecado original, cuja versão doméstica ressalta a atrofia na capacidade das economias menos desenvolvidas de se financiarem a longo prazo mediante emissão de títulos prefixados, denominados em moeda local no âmbito do mercado doméstico.

Ao longo da década de 2000, apoiado nos preços internacionais favoráveis às commodities, no acúmulo de reservas e na política de distribuição de renda, o Governo Federal brasileiro logrou êxito em reduzir o peso da dívida externa pública. Entretanto, tal estratégica se processou ao custo da ampliação substancial da base de endividamento público interno via mercado mobiliário. As principais mudanças processadas no mercado mobiliário brasileiro consistiram no aumento expressivo das emissóes de títulos prefixados, reduçóes dos títulos indexados à taxa de juros e a praticamente extinção das emissóes dos títulos atrelados à moeda estrangeira.

Uma análise ligeira e superficial sobre o que essas transformações representam pode gerar uma supervalorização dos verdadeiros benefícios experimentados no perfil e na qualidade da dívida mobiliária interna no Brasil. Isso porque a dívida interna continua majoritariamente pós-fixada, e as emissóes prefixadas além de ainda serem incipientes, apresentam um caráter completamente de curto prazo. $\mathrm{Na}$ realidade, a eliminação da relevância dos títulos cambiais na composição total da DPMFI foi compensada pela elevação significativa dos títulos indexados à inflação. Disso tem-se uma dívida pública no mercado de títulos marcada pela forte indexação ao nível de preços e pelas emissóes prefixadas de curto prazo, somado a uma parcela ainda considerável de títulos indexados à SELIC.

O quadro se torna ainda mais crítico quando analisado sob a ótica dos prazos médios e da maturidade dos títulos públicos emitidos. Com exceção dos títulos cambiais, que perderam quase que completamente a sua relevância na composição da dívida nacional interna, apenas os títulos indexados à inflação são emitidos em uma quantidade expressiva com resgate de longo prazo, dado a aversão dos agentes nacionais aos riscos inflacionários. Ademais, tanto os títulos prefixados quanto os vinculados à SELIC são de curto prazo. O cenário exposto "confessa" a existência do pecado brasileiro interno, ou seja, sinaliza para fortes evidências que sugerem a sua ocorrência, mas não substitui à necessidade de se calcular a magnitude real do pecado original doméstico no País mediante índices específicos.

Os resultados dos cálculos dos índices para o período entre janeiro de 2001 a abril de 2016 revelam que houve uma transformação da forma como que se manifesta o pecado doméstico no Brasil, sem que isso represente qualquer mudança sensível em sua magnitude, 
dado o aumento das indexações ao nível de preços, dos prefixados de curto prazo e da relevante participaçáo dos títulos indexados à taxa de juros. Mais precisamente, uma das inferências mais marcantes do trabalho foi identificar que os esforços do Governo Federal ao longo da década de 2000, implicaram na transmutaçâo da forma como se apresenta o pecado original doméstico, com ausência de qualquer alteração paradigmática do problema.

Ao longo da década de 2000, apoiado nos preços internacionais favoráveis às commodities, no acúmulo de reservas e na política de distribuição de renda, o Governo Federal brasileiro logrou êxito em reduzir o peso da dívida externa pública. Entretanto, tal estratégia se processou ao custo da ampliaçáo substancial da base de endividamento público interno via mercado mobiliário. As principais mudanças processadas no mercado mobiliário brasileiro consistiram no aumento expressivo das emissões de títulos prefixados, reduçóes dos títulos indexados à taxa de juros e a praticamente extinção das emissôes dos títulos atrelados à moeda estrangeira.

A dívida interna continua majoritariamente pós-fixada, e as emissóes prefixadas além de ainda serem incipientes, apresentam um caráter de curto prazo. Na realidade, a eliminaçáo da relevância dos títulos cambiais na composição total da DPMFI foi compensada pela elevação significativa dos títulos indexados à inflação. Disso tem-se uma dívida pública no mercado de títulos marcado pela forte indexação ao nível de preços e pelas emissôes prefixadas de curto prazo, somada a uma parcela persistentemente considerável de títulos indexados à SELIC. O quadro se torna ainda mais crítico quando analisado sob a ótica dos prazos médios e da maturidade dos títulos públicos emitidos.

Os resultados dos cálculos dos índices revelam que houve uma transformaçáo da forma como que se manifesta o pecado doméstico no Brasil, sem que isso represente qualquer mudança sensível em sua magnitude. Uma das inferências mais marcantes do trabalho foi identificar que os esforços do Governo Federal ao longo da década de 2000 implicaram na transmutação da forma como se apresenta o pecado original doméstico, com ausência de qualquer alteração paradigmática do problema. Uma vez que se observou que a inflaçáo e a taxa de juros se aproximaram no final da série aos níveis observados no início da década de 2000, uma gestấo racional e coerente das mesmas torna-se fundamental para a proteção contra defaults, moratórias e insolvência da dívida brasileira interna. No entanto, medidas paliativas não enfrentam o múnus do pecado doméstico no Brasil, a saber: a forte indexação que caracteriza as emissóes do setor público federal.

\section{REFERÊNCIAS}

ATHAYDE, D.R; VIANNA, A.C Dívida pública brasileira: uma análise comparativa dos três principais indicadores de esforço fiscal do governo. Nova Econ., v.25, n.2, p.403-420, ago.2015.

BANCO CENTRAL DO BRASL. Boletim do Banco Central do Brasil, v. 45, n.12, Dez. 2009. Disponível em: < http://www.bcb.gov.br/ftp/histbole/Bol200912p.pdf>. Acesso em 15 set. 2016. 
BENVENHO, A.C. CAPM na Avaliação de Empreendimentos Industriais: uma abordagem pelo Beta Total. XVI COBREAP - Congresso Brasileiro de Engenharia de Avaliaçóes e Perícias - IBAPE/AM, 2011.

BLOOMBERG THE COMPANY \& ITS PRODUCTS. Bloomberg Brasil: empresas brasileiras podem se afastar de dívida em dólar. Disponível em: https:/www.bloomberg. com.br/blog/empresas-brasileiras-podem-se-afastar-de-divida-em-dolar/. Acesso em 15 set. 2016.

CASTRO, J.A; RIBEIRO, J.A; CHAVES, J.V; DUARTE, B.C; SIMÓES, H.B. Gasto Social e Política Macroeconômica: trajetórias e tensões no período 1995-2005. Texto Para Discussão, n.1324, 2008.

CINTRA, M.A; ACIOLY, L. O financiamento das contas externas brasileiras: 2003-2010. In: MONTEIRO, A. et. al. Brasil em desenvolvimento 2011. Brasília: Ipea, 2012.

CRUZ, F.I.L. O ajuste fiscal do Governo Brasileiro de onde viemos e para onde vamos? Indic. Econ. FEE, Porto Alegre, v.43, n.3, p.45-56, 2016.

EICHENGREEN; HAUSMANN, R. Exchange rates and financial fragility.

Cambridge: National Bureau of Economic Research (NBER Working Paper, n.7418), 1999.

EICHENGREEN; HAUSMANN, R.; PANIZZA, U. The Pain of Original Sin. In: EICHENGREEN, B; HAUSMANN, R. (Org). Other People's Money: Debt Denomination and Financial Instability in Emerging-Market Economies. Chicago: University of Chicago Press, p.13-48, 2005a.

EPSTEJN, M. Microestrutura de mercado: os desafios atuais para a ampliaçáo da base de investidores no mercado de títulos públicos no Brasil. Insper, São Paulo, 2011. Disponível em: < http://dspace.insper.edu.br/xmlui/bitstream/handle/11224/523/ Monica\%20Epstejn_trabalho.pdf?sequence=1>. Acesso em: 17 set. 2016.

GOMES, C; AIDAR, O; LAUX, G; LIBERATO, D. Uma análise da literatura do pecado original aplicada ao endividamento público e privado brasileiro. In: XXXV Encontro Nacional de Economia (ANPEC), 2007. Disponível em: <http:/www.anpec. org.br/encontro2007/artigos/A07A017.pdf.>. Acesso em 12 fev.2016.

HAUSMANN, R; PANIZZA, U. On the determinants of Original Sin: an empirical investigation. Journal of International Money and Finance, v.22, n.7, p.957-990, dez.2003.

KOLLER, T; GOEDHART, M; WESSELS, D. Valuation-measuring and managing the value of companies. $4^{\circ} \mathrm{ed}$; John Wiley \& Sons Inc, 2005. 
MATTOS, F.A.M. Avanços e dificuldades para o mercado de trabalho. Estudos Avançado, n.29, v.85, 2015.

MEHL, A; REYNALD, J. The determinants of "domestic" original sin in emerging market economies. Frankfurt: European Central Bank, 2005 (Working Paper Series, n.560).

\section{SECRETARIA DO TESOURO NACIONAL (STN). Característica dos títulos}

ofertados no Tesouro Direto. Brasília, 2016. Disponível em: <http://www3.tesouro.gov. br/tesouro_direto/consulta_titulos_novosite/download/Caracteristicas.pdf>. Acesso em 10 set. 2016.

SILVA, A.C; GARRIDO, F.E.P; CARVALHO, L.O. Evolução recente do mercado de títulos da dívida pública federal. In: SILVA, A.C et al. (Org.). Dívida Pública: a experiência brasileira. 1. ed. Brasília: Secretaria do Tesouro Nacional: Banco Mundial, 2009.

SOUZA, E.A. Influência dos títulos americanos no mercado de capitais brasileiro. 62f. Trabalho de conclusão do Curso de Graduação em Administração, Departamento de Ciências Administrativas, Universidade Federal do Rio Grande do Sul, Porto Alegre, 2015.

WORLD BANK. World Bank Open Data: free and open access to global development data. Disponível em: < http://data.worldbank.org/>. Acesso em 15 nov.2016. 
ANEXO - A

Tabela 1 - Índices DSIN2 e DSIN3 (2000-2006)

\begin{tabular}{|c|c|c|c|c|c|c|c|c|c|c|c|c|c|c|}
\hline \multirow{3}{*}{ Mês } & \multicolumn{2}{|c|}{2000} & \multicolumn{2}{|c|}{$\mathbf{2 0 0 1}$} & \multicolumn{2}{c|}{$\mathbf{2 0 0 2}$} & \multicolumn{2}{c|}{$\mathbf{2 0 0 3}$} & \multicolumn{2}{c|}{2004} & \multicolumn{2}{|c|}{2005} & \multicolumn{2}{c|}{2006} \\
\cline { 2 - 17 } & $\begin{array}{c}\text { DSI } \\
\text { N2 }\end{array}$ & $\begin{array}{c}\text { DSI } \\
\text { N3 }\end{array}$ & $\begin{array}{c}\text { DSI } \\
\text { N2 }\end{array}$ & $\begin{array}{c}\text { DSI } \\
\text { N3 }\end{array}$ & $\begin{array}{c}\text { DSI } \\
\text { N2 }\end{array}$ & $\begin{array}{c}\text { DSI } \\
\text { N3 }\end{array}$ & $\begin{array}{c}\text { DSI } \\
\text { N2 }\end{array}$ & $\begin{array}{c}\text { DSI } \\
\text { N3 }\end{array}$ & $\begin{array}{c}\text { DSI } \\
\text { N2 }\end{array}$ & $\begin{array}{c}\text { DSI } \\
\text { N3 }\end{array}$ & $\begin{array}{c}\text { DSI } \\
\text { N2 }\end{array}$ & $\begin{array}{c}\text { DSI } \\
\text { N3 }\end{array}$ & $\begin{array}{c}\text { DSI } \\
\text { N2 }\end{array}$ & $\begin{array}{c}\text { DSI } \\
\text { N3 }\end{array}$ \\
\hline Jan. & 1 & 1 & 1 & 1 & 1 & 1 & 1 & 1 & 0.979 & 1 & 0.993 & 1 & 1 & 1 \\
\hline Fev. & 1 & 1 & 1 & 1 & 1 & 1 & 1 & 1 & 0.961 & 1 & 0.994 & 1 & 0.823 & 1 \\
\hline Mar. & 1 & 1 & 1 & 1 & 1 & 1 & 1 & 1 & 0.977 & 1 & 1.00 & 1 & 0.821 & 1 \\
\hline Abr. & 1 & 1 & 1 & 1 & 1 & 1 & 1 & 1 & 0.980 & 1 & 1.00 & 1 & 0.957 & 1 \\
\hline Mai. & 1 & 1 & 1 & 1 & 1 & 1 & 1 & 1 & 0.968 & 1 & 1.00 & 1 & 0.922 & 1 \\
\hline Jun. & 1 & 1 & 1 & 1 & 1 & 1 & 1 & 1 & 0.989 & 1 & 0.989 & 1 & 0.994 & 1 \\
\hline Jul. & 1 & 1 & 1 & 1 & 1 & 1 & 1 & 1 & 0.992 & 1 & 0.992 & 1 & 0.992 & 1 \\
\hline Ago. & 1 & 1 & 1 & 1 & 1 & 1 & 1 & 1 & 0.997 & 1 & 0.994 & 1 & 0.994 & 1 \\
\hline Set. & 1 & 1 & 1 & 1 & 1 & 1 & 1 & 1 & 0.988 & 1 & 1 & 1 & 0.998 & 1 \\
\hline Out. & 1 & 1 & 1 & 1 & 1 & 1 & 0.990 & 1 & 0.978 & 1 & 1 & 1 & 0.976 & 1 \\
\hline Nov. & 1 & 1 & 1 & 1 & 1 & 1 & 0.990 & 1 & 1 & 1 & 1 & 1 & 0.986 & 1 \\
\hline Dez. & 1 & 1 & 1 & 1 & 1 & 1 & 0.990 & 1 & 1 & 1 & 0.990 & 1 & 0.993 & 1 \\
\hline
\end{tabular}

Fonte: Elaboração própria com base nos dados da pesquisa.

\section{ANEXO - B}

Tabela 2 - Índices DSIN2 e DSIN3 (2007-2016)

\begin{tabular}{|c|c|c|c|c|c|c|c|c|c|c|c|c|c|c|c|c|c|c|c|c|}
\hline \multirow[b]{2}{*}{ Mês } & \multicolumn{2}{|c|}{2007} & \multicolumn{2}{|c|}{2008} & \multicolumn{2}{|c|}{2009} & \multicolumn{2}{|c|}{2010} & \multicolumn{2}{|c|}{2011} & \multicolumn{2}{|c|}{2012} & \multicolumn{2}{|c|}{2013} & \multicolumn{2}{|c|}{2014} & \multicolumn{2}{|c|}{2015} & \multicolumn{2}{|c|}{2016} \\
\hline & \begin{tabular}{|c|} 
DSI \\
N2
\end{tabular} & $\begin{array}{c}\text { DSI } \\
\text { N3 }\end{array}$ & $\begin{array}{c}\text { DSI } \\
\text { N2 }\end{array}$ & $\begin{array}{c}\text { DSI } \\
\text { N3 }\end{array}$ & \begin{tabular}{|c|} 
DSI \\
N2
\end{tabular} & $\begin{array}{c}\text { DSI } \\
\text { N3 }\end{array}$ & $\begin{array}{l}\text { DSI } \\
\text { N2 }\end{array}$ & $\begin{array}{c}\text { DSI } \\
\text { N3 }\end{array}$ & $\begin{array}{c}\text { DSI } \\
\text { N2 }\end{array}$ & $\begin{array}{c}\text { DSI } \\
\text { N3 }\end{array}$ & $\begin{array}{l}\text { DSI } \\
\text { N2 }\end{array}$ & $\begin{array}{l}\text { DSI } \\
\text { N3 }\end{array}$ & $\begin{array}{l}\text { DSI } \\
\text { N2 }\end{array}$ & $\begin{array}{c}\text { DSI } \\
\text { N3 }\end{array}$ & $\begin{array}{l}\text { DSI } \\
\text { N2 }\end{array}$ & \begin{tabular}{|c|} 
DSI \\
N3
\end{tabular} & $\begin{array}{l}\text { DSI } \\
\text { N2 }\end{array}$ & $\begin{array}{c}\text { DSI } \\
\text { N3 }\end{array}$ & $\begin{array}{l}\text { DSI } \\
\text { N2 }\end{array}$ & $\begin{array}{l}\text { DSI } \\
\text { N3 }\end{array}$ \\
\hline an. & 997 & 1 & 0.962 & 1 & 0.978 & 1 & 0.980 & 1 & 0.961 & 1 & 0.969 & 1 & 0.898 & 1 & 0.823 & 0.878 & 0.862 & 0.890 & 0.942 & 0.947 \\
\hline Fev. & 983 & 1 & 0.993 & 1 & 0.992 & 1 & 0.842 & 1 & 0.963 & 1 & 0.961 & 1 & 0.936 & 1 & 0.895 & 0.979 & 0.914 & 0.941 & 0.932 & 0.952 \\
\hline Mar. & 83 & 1 & 0.972 & 1 & 60 & 1 & 0.985 & 1 & 0.962 & 1 & 0.945 & 1 & 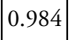 & 1 & 47 & 0.974 & 86 & 0.997 & 59 & 916 \\
\hline Abr. & 965 & 1 & 963 & 1 & .946 & 1 & 924 & 1 & 0.983 & 1 & 0.883 & 1 & 0.964 & 1 & 0.874 & 0.901 & 0.989 & 1 & 0.931 & 0.975 \\
\hline Mai & 967 & 1 & 0.961 & 1 & 0.986 & 1 & 0.963 & 1 & 0.975 & 1 & 0.893 & 1 & 0.895 & 1 & 0.919 & 0.973 & 0.982 & 1 & 0.889 & 0.920 \\
\hline Jun. & 0.830 & 1 & 0.966 & 1 & 0.984 & 1 & 0.994 & 1 & 0.968 & 1 & 0 & 1 & 0.918 & 1 & 0.902 & 0.955 & 0.97 & 1 & 0.893 & 0.9 \\
\hline Jul. & 13 & 1 & 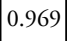 & 1 & 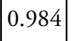 & 1 & 0.997 & 1 & 0 & 1 & 6 & 1 & 954 & 1 & 886 & 0.953 & 0.985 & 1 & .858 & 0.928 \\
\hline Ago. & 0.956 & 1 & 0.970 & 1 & 0.979 & 1 & 0.982 & 1 & 0.946 & 1 & 0.927 & 1 & 0.982 & 1 & 0.796 & 0.854 & 0.981 & 1 & 0.895 & 0.954 \\
\hline Set. & 956 & 1 & 0.939 & 1 & 0.967 & 1 & 0.940 & 1 & 0.951 & 1 & 0.938 & 1 & 0.979 & 1 & 0.960 & 0.995 & 0.991 & 1 & 0.922 & 0.97 \\
\hline Out. & 0.981 & 1 & 0.959 & 1 & 0.987 & 1 & 0.993 & 1 & 0.950 & 1 & 0.974 & 1 & 0.976 & 1 & 0.898 & 0.921 & 0.975 & 1 & 0.900 & 0.96 \\
\hline Nov. & 0.977 & 1 & 970 & 1 & 0.963 & 1 & 55 & 1 & 0.956 & 1 & 0.913 & 1 & 0.945 & 1 & 0.953 & 0.980 & 0.975 & 1 & 0.963 & 0.978 \\
\hline Dez. & 0.976 & 1 & 990 & 1 & 0.972 & 1 & 964 & 1 & 0.952 & 1 & 0.984 & 1 & 0.954 & 1 & 0.894 & 0.907 & 0.984 & 1 & 0.952 & 0.9 \\
\hline
\end{tabular}

Fonte: Elaboração própria com base nos dados da pesquisa. 